\title{
Canadian Institute of Forestry/Institut Forestier du Canada
}

\author{
Towards 21st Century Forestry \\ Vers la foresterie de $21^{\mathrm{e}}$ siècle \\ Montréal, Québec \\ September 26-30, 1993 - 26-30 septembre 1993
}

The Forestry Chronicle

Volume 69, Number 6

December 1993

Annual Meeting Supplement
The Forestry Chronicle

Volume 69, numéro 6

décembre 1993

supplément de l'assemblée

annuelle

\section{President's Report,} 1992-93

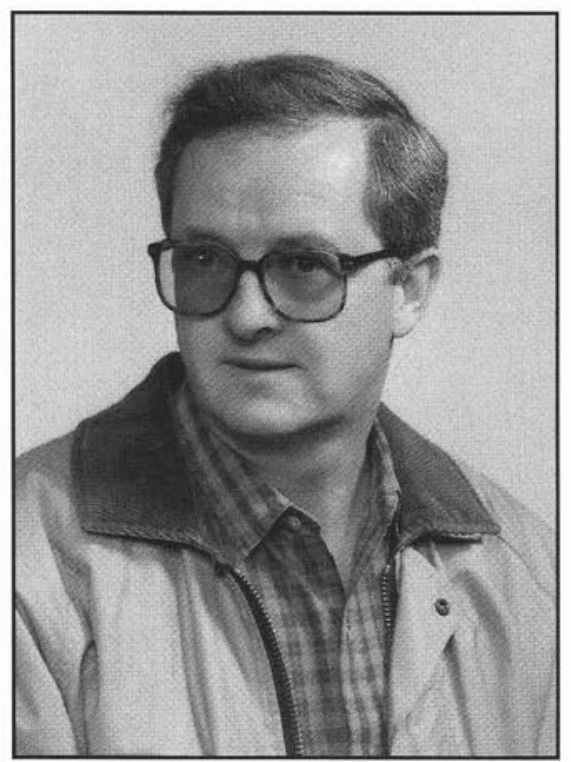

The past year has seen many changes in the forest sector.

- Both Forestry Canada and the expectation that the Forest Resource Development Agreements would be renewed were casualties of the 1993 spring budget.

Forestry Canada has reappeared as the Canadian Forest Service within the new Department of Natural Ressources. The government may find a way to renew the federal/provincial agreements, but not in the same form.

- The subject of community managed forests is starting to be discussed in several provinces. Widespread adoption of community managed forests would create some interesting changes.

\section{Rapport du président 1992-93}

Le secteur forestier a connu plusieurs changements au cours de la dernière année.

- Forêts Canada et la possibilité que soit renouvelée les ententes de mise en valeur des ressources forestières ont été les victimes du budget du printemps de 1993.

Forêts Canada est redevenu le Service canadien des Forêts au soin du nouveau ministère des Ressources naturelles. Le gouvernement pourrait trouver une façon de renouveler les ententes fédérales-provinciales, mais sous une autre forme.

- Les forêts gérées par les communautés font l'objet de discussions dans plusieurs provinces. L'adoption à grande échelle de forêts gérées par les communautés entraînerait plusieurs changements intéressants.

Cela pourrait:

- décentraliser la prise de décision sur la gestion des forêts;

- dans une situation où le bois n'est alloué qu'à un utilisateur spécifique, générer une rupture du système quasimonopolistique d'approvisionnement en bois et introduire quelques éléments additionnels de libre marché dans le système;

- légitimiser probablement les décisions prises en aménagement forestier par l'entremise de la participation et de l'appui des communautés.

- La certification des aspects de l'aménagement forestier au sein du processus de production de produits forestier est devenue un sujet courant de discussion. On prévoit qu'il y aura sous peu une demande au niveau du marché pour des produits forestiers tirés de forêts aménagées de façon durable.

Plusieurs personnes sont engagées dans des discussions menant à la foresterie durable.

Quarante et un pays se sont rencontrés à Montréal sous 
It would:

- decentralize forest management decision making.

- If wood produced on community forests is not committed to a specific wood user it will break up the quasimonopolistic wood supply system and introduce some additional free market forces into the system.

- perhaps legitimize forest management decisions through community involvement and support.

- The topic of certification of the forest managment aspects of the production of the forest products has become a common topic of discussion. It is expected that there will soon be a demand in the market place for wood products from substainably managed forests.

Many people are engaged in discussion of criteria to define substainable forestry.

Forty-one nations have met in Montreal under the aegis of the Conference on Security and Co-operation in Europe to discuss criteria for the substainable management of temperate and boreal forests.

Look to Canadians to take the lead in this matter.

- The pulp and paper industry is not making money. Our solid wood products industry is enjoying reasonable demand and fairly good prices, but trade in softwood lumber with the USA is still subject to duties and countervail actions. Generally the industry is starting to emerge from the most difficult period since the Depression of the 1930s.

Newsprint and pulp are not expected to show a profit until 1994/95.

No one should underestimate the amount of effort, investment and ingenuity that will be required to rebuild the industry in Canada and make it profitable once again. Nor should we understate the importance of rebuilding to the Canadian economy.

- Foresters across Canada are still the subject of criticism or even plain distrust. People do not believe that our practices are substainable. Often they do not like what they see when they go to the woods.

- Several Scandinavian forest equipment companies have established permanent sales and assembly operations in North America. Canadian and American equipment suppliers are starting to develop new machines and attachments. These will provide us with the ability to implement a wider range of silvicultural treatments than in the past.

- Foresters are taking a second look at the way we work in the woods. More partial cut systems are now being used across Canada. These systems will become even more popular in the near future.

- Several provinces are reviewing their AACs. Reductions are expected and will be due to changes in land use, establishment of reserves for various purposes, concern about the affects of past reforestation failures and over commitment of wood to industry.

What has the Institute been doing during this eventful year? l'égide de la Conférence sur la sécurité et la coopération en Europe afin de discuter des critères relatifs à la gestion durable des forêts tempérées et boréales. Les Canadiens sont les meneurs sur ce sujet.

- L'industrie des pâtes et papiers génèrent actuellement peu de profits. Notre industrie des produits de bois solide connaît une bonne demande ainsi que de bons prix, mais le commerce du bois de sciage de résineux avec les États-Unis demeure assujetti à des tarifs douaniers et à des représailles. De façon globale, l'industrie commence à émerger de la plus difficile période que nous avons connue depuis la Dépression des années 30.

Le papier journal et la pâte ne devraient pas générer de profits avant 1994-95.

Personne ne devrait sous-estimer l'importance des efforts, des investissements et de l'ingéniosité qui seront requis pour rebâtir cette industrie au Canada et pour la rendre à nouveau rentable. Nous ne devrions pas sous-estimer également l'importance de cette reconstruction pour l'économie canadienne.

- Les forestiers de tout le Canada font encore l'objet de critiques ou encore de simple méfiance. Les gens ne croient pas que nos pratiques soient durables. Le plus souvent ils n'apprécient pas ce qu'ils voient lorsqu'ils vont en forêt.

- Plusieurs compagnies scandinaves de machinerie forestière ont établi des points de vente et des centre d'assemblage permanents en Amérique du Nord. Les manufacturiers canadiens et américains s'intéressent à la conception de nouvelles machines et à de nouveaux accessoires. Celà nous permettra de pouvoir accéder à une plus grande gamme de traitements sylvicoles que par le passé.

- Les forestiers considèrent sous un angle différent nos méthodes de travail en forêt. De plus en plus, les coupes partielles font leur chemin au Canada. Ces méthodes seront encore plus populaires dans un proche avenir.

- Plusieurs provinces procèdent actuellement à la révision de leur P.A.C. Des réductions sont prévues et seront le résultat des changements dans l'utilisation du territoire, de la mise en place de réserves à diverses fins, d'inquiétude entourant les échecs antérieurs de reboisement et de l'engagement excessif de bois pour l'industrie.

Qu'est-ce que l'Institut a fait au cours de cette année remplie d'événements?

- Nous avons remis un jonc aux 292 gradués en foresterie du Canada.

- En réponse à une résolution adoptée lors de l'assemblée annuelle de 1992 , le comité exécutif a préparé un mémoire sur les modifications de l'utilisation du territoire, la réduction des P.A.C. et sur la nécessité en général d'avoir de nouvelles données d'inventaire forestier, de croissance et de rendement pour pouvoir faire les ajustements requis en fonction des niveaux de récolte. Des décisions reposant sur une information périmée risquent de fixer des P.A.C à des niveaux irréalistes tout en créant des impacts socio- 
1993-1994 CIF/IFC Executive Committee. Left to right: Tony Rotherham (Past President), Peter Murphy (President), Hap Oldham (1st Vice-President), Steve Tolnai (2nd VicePresident), Chris Lee (Executive Director)

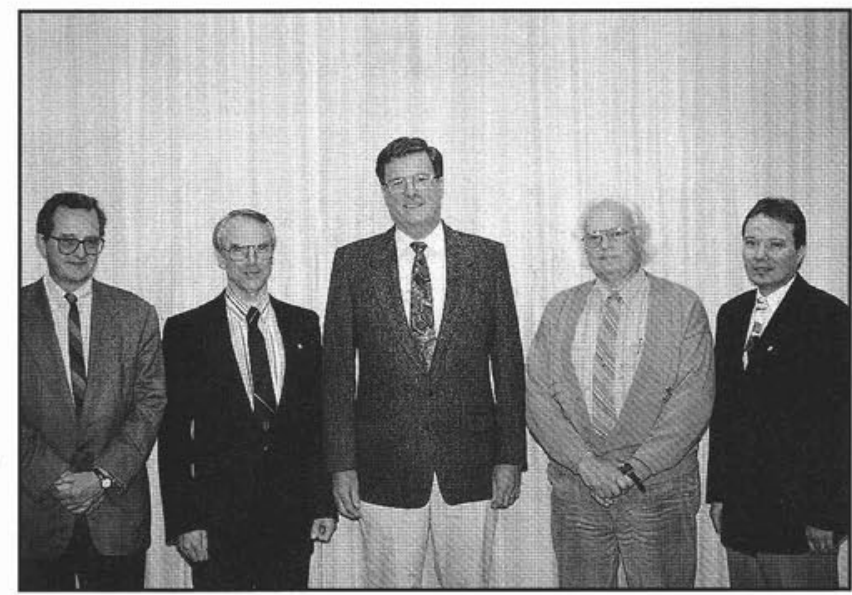

- We presented CIF\IFC rings to 292 forestry graduates across the country.

- In response to a resolution at the 1992 Annual General Meeting, the Executive Committee prepared a brief on land use changes, AAC reductions and the general need for new forest inventories and growth and yield data as a basis for making any adjustments in harvest levels. Decisions based on out-dated information risk setting AACs at unrealistic levels with unnecessary socio-economic impacts. This brief was sent to provincial and federal cabinet ministers responsible for revenue, health, education, industry and forests. The brief was also sent to 20-30 influential newspapers across the country.

- The Institute participated in National Forest Week in Ottawa. With the Honourable John Fraser, Speaker of the House, we co-hosted a reception on Parliament Hill attended by some 60 influential people including 34 MPs. We also had discussions with Minister Oberle and opposition forestry critics. The Honourable John Fraser was made an Honorary Member of the $\mathrm{CIF} / \mathrm{IFC}$ for his interest and support for forestry.

- We are involved in monitoring the implementation of the National Forest Strategy as well as working on the evolution of codes for professional foresters.

- We published six excellent issue of The Forestry Chronicle.

- Members of the executive Committee attended Section meetings in Thunder Bay, Ontario, Fredericton, New Brunswick, in Nova Scotia and Alberta.

- We are involved in discussions with a committee of the Ontario Professional Foresters Association on how the OPFA and CIF/IFC can best represent the interests of foresters and forestry in Ontario.

- Through the Canadian Federation of Professional Foresters' Associations, we are involved in planning the seminar which is being organized by the Forestry Deans. économiques inutiles. Ce mémoire à été remis aux ministres provinciaux et fédéraux responsables du revenu, de la santé, de l'éducation, de l'industrie et des forêts. Ce mémoire a été également acheminé à près de 30 journaux importants du pays.

- L'Institut a participé à la Semaine nationale des forêts à Ottawa. En collaboration avec l'Honorable John Fraser, président de la Chambre des Communes, nous avons organisé une réception sur la Colline parlementaire à laquelle ont assisté quelque 60 personnalités influentes dont 34 députés fédéraux. Nous avons également discuté avec le ministre Oberle et les critiques de l'opposition en matière de foresterie. L'Honorable John Fraser est devenu membre honoraire de l'IFC/CIF en vertu de son intérêt et de son appui à la foresterie.

- Nous participons au suivi de l'implantation de la Stratégie nationale sur les forêts ainsi qu'aux travaux découlant de l'évolution des codes pour les forestiers pro-

- Nous avons publié six excellents numéros du Forestry Chronicle.

- Les membres du comité exécutif ont assisté à des réunions de section à Thunder Bay en Ontario, à Frédéricton au Nouveau-Brunswick, en Nouvelle-Écosse et en Alberta.

- Nous participons à des discussions avec un comité de l'Ontario Professional Foresters Association à savoir comment l'OPFA et L'IFC/CIF peuvent mieux servir les intéret des forestiers et de la foresterie en Ontario.

- Par l'entremise de la Fédération canadienne des associations professionnelles de forestiers, nous participons à la préparation d'un séminaire organisé par les doyens des facultés de foresterie. Ce séminaire, qui aura lieu à fessionnels. 
This seminar, to be held in Quebec City, December 8, 9 and 10, 1993, will discuss how forest management will be practised in the next decades and the way university forestry curriculae must change to provide foresters with the skills and knowledge required to do the job.

- A joint effort with the "Ordre des ingénieurs forestiers du Québec (OIFQ)" has produced a discussion paper on criteria with which to measure progress towards sustainable forestry. The discussion paper includes 28 indicators, characteristics and objectives of sustainable management. The discussion paper is included in this issue of the Chronicle.

- The institute was represented in an advisory role on the Canadian Delegation to the CSCE Expert Seminar on SustainableDevelopment of Boreal and Temperate Forests. Steve Tolnai, incoming Vice-President of CIF/IFC was our representative.

Steve presented the OIFQ/CIF joint discussion paper on sustainable forestry to the Canadian delegation. It was also distributed to several national delegations.

\section{The Executive Director's Report Introduction}

This is the report for my third year as Executive Director. It has proven to be no less challenging and hectic than the previous two. The Executive Committee has asked me to stay for at least one more year after this, as an addition to my original three year contract.

Some of the highlights of 1992-93 include an excellent 1992 Annual meeting in Vancouver; our decision to become partners in the organization of the Second National Silviculture Conference; involvement with the RPF Associations with our president as chair of the Canadian Federation of Professional Foresters Associations (CFPFA); the creation of a poster and brochures to encourage both students and potential active members to consider CIF/IFC membership; and the opportunity to work with the hundreds of dedicated volunteers who make up the Institute.

\section{Finances}

A detailed report from the finance Committee is presented; however, I will provide a brief outline. Membership dues were much lower than budgeted and revenues from The Forestry Chronicle were not as strong as they were in 1991-92. These two factors combined to seriously draw down income of the Institute. Fortunately, the 1992 AGM was very successful both in content and financially and over $\$ 16,000$ was received by National Office from HAMPCO 1992! With these funds, we are expecting a close to break even situation for 1992-93.

\section{Membership}

As in previous years, we were quite successful at attracting new members but just as successful at failing to keep existing members. We tried to improve our contact with
Québec les 8, 9 et 10 décembre 1993, traitera de comment sera pratiqué l'aménagement forestier au cours des prochaines décennies et de quelle façon doit être modifiée les programmes de foresterie pour fournir aux forestiers les compétences et les connaissances requises pour faire leur travail.

- Une collaboration avec l'Ordre des ingénieurs forestiers du Québec (OIFQ) a permis de produire un mémoire sur les critères qui mesurent le progrès réalisé en matière de foresterie durable. Ce mémoire comprend 28 indicateurs, caractéristiques et objectifs d'aménagement durable. Ce mémoire est inclus dans ce numéro du chronicle.

- L'Institut était représenté à titre de conseiller de la délégation canadienne qui participait au séminaire d'experts de la CSCE sur le développement durable des forêts boréales et tempérées. Steve Tolnai, premier-président désigné de l'IFC/CIF était notre représentant.

Steve à remis le mémoire conjoint de l'OIFQ/IFC sur la foresterie durable à la délégation canadienne. Il a été également remis à quelques délégations nationales.

\section{Rapport du directeur executif Introduction}

Ce document représente mon troisième rapport en tant que directeur exécutif. L'année écoulée s'est révélée autant remplie de défis et de rebondissements que les deux autres. Le comité exécutif m'a demandé de demeurer en poste pour un an de plus que ce qui avait été convenu dans mon contrat de trois ans.

Les principaux points saillants de 1992-93 comprennent l'excellent congrès de 1992 qui a lieu à Vancouver; la décision de devenir partenaire dans l'organisation de la deuxième conférence sur la sylviculture; la participation au sein des associations professionnelles de forestiers dont notre président était le président de la Fédération canadienne des associations professionnelles de forestiers (FCAPF); la réalisation d'une affiche et de dépliants pour encourager les étudiants ainsi que les membres potentiels à devenir membres de l'IFC; et la possibilité de travailler avec des centaines de volontaires impliqués à faire bouger l'Institut.

\section{Finances}

Un rapport détaillé du comité des finances est disponible; cependant $\mathrm{j}$ 'aimerais souligner certains points. Les revenus des cotisations des membres ont été de beaucoup inférieurs à ce qui avaient été budgétés et les revenus du Forestry Chronicle n'ont pas été aussi élevés qu'en 1991-92. Ces deux facteurs se sont additionnés pour réduire sérieusement les revenus de l'Institut. Heureusement, l'assemblée générale annuelle de 1992 a connu à la fois un succès au niveau du contenu et des résultats financiers et plus de $15000 \$$ ont été versés par HAMPCO 1992 à la caisse du siège social. Grâce à ses fonds, nous devrions atteindre l'équilibre budgétaire pour 1992-93. 


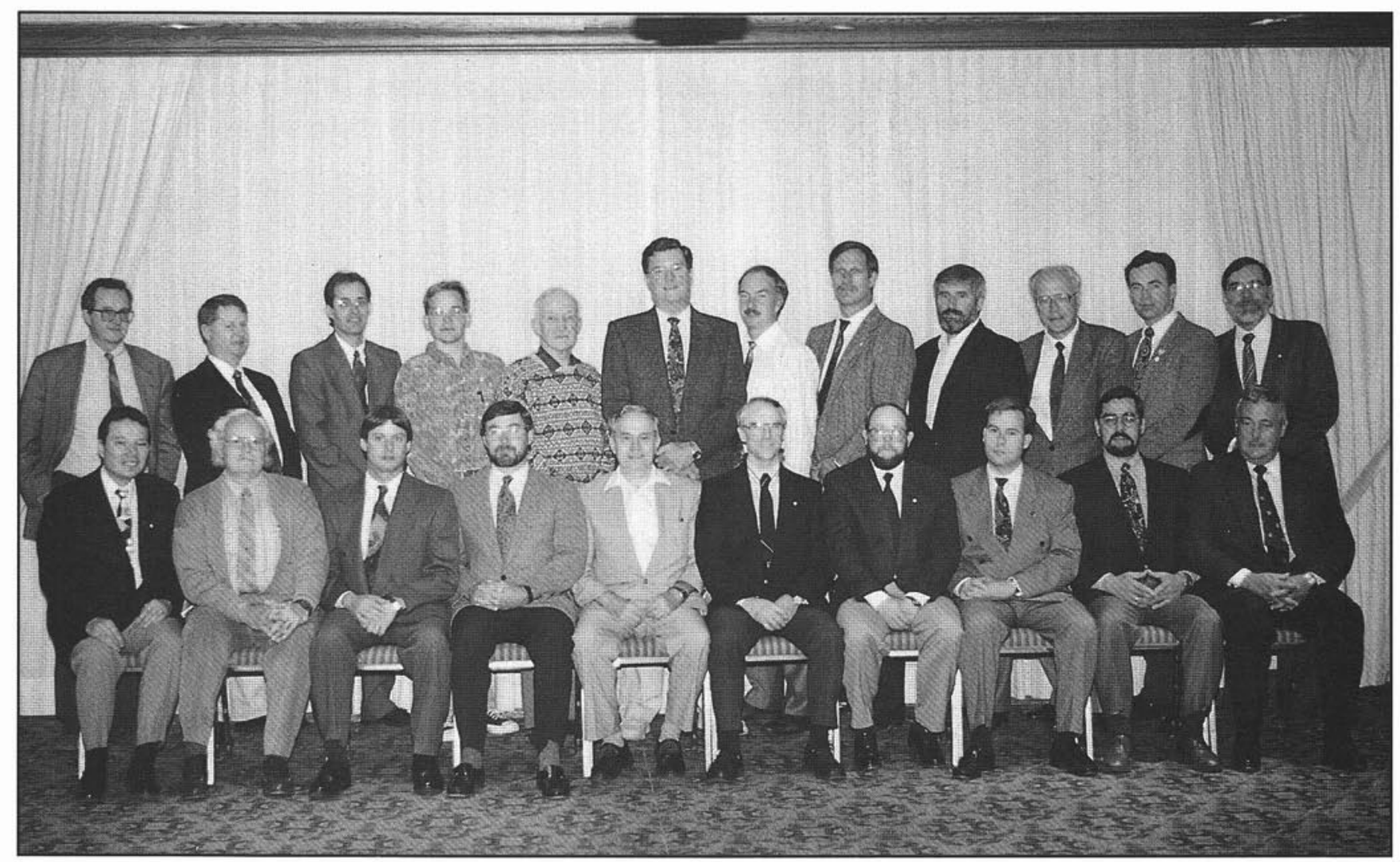

Board of Directors at the CIF/IFC Annual Meeting, Montreal, September 1993. Back row (left to right): Tony Rotherham, Arden Whidden, Rick Archibald, Rick Braam, Dan MacArthur, Hap Oldham, Peter Street, Ian Corns, Bob Yatkowski, Dolf Wynia, Don Couch.

Front row (left to right) Chris Lee, Steve Tolnai, Richard Lipman, David Saltes. Denes Bazjak, Peter Murphy, Michael Newman, David Carson, François Julien, Greg Taylor.

Sections and with individual members so that they would be better aware of CIF/IFC activities and therefore more likely to retain their memberships. We also kept the 199394 dues the same as 1992-93 and, following a suggestion from the Maritime Section, we announced an incentive program to sign up three new members and not have to pay your dues. The incentive program, coupled with the brochures and posters, should begin to generate results in 1993-94.

\section{The Forestry Chronicle}

The Forestry Chronicle staff (Jim Cayford and Darwin Burgess, Editors, and Tim Fenton, Production Manager) are the same group that has been in place since 1990-91. Their work continues to evolve and improve. Tangible evidence of their efforts is seen in a constant demand by authors to have their papers published, resulting in good revenues from both page charges and reprints, solid advertising revenues, and excellent comments and reviews from members, advertisers and outside organizations. Despite the fact that the net cost of The Forestry Chronicle was slightly higher in 1992-93 than it was in 1991-92, the fact remains that the cost per member to receive this outstanding publication is very low.

\section{Other Publications}

The Forestry Update/Information forestière was again

\section{Membres}

Comme par les années passées, nous avons été en mesure d'attirer plusieurs nouveaux membres, mais autant dans l'incapacité de retenir nos membres actuels. Nous avons tenté d'améliorer nos contacts avec les sections et avec chacun des membres de telle sorte qu'ils soient mieux au courant des activités de l'IFC, et en conséquence plus enclins à demeurer membres. Nous avons également geler les frais d'adhésion de 1993-94 au même niveau que ceux de 1992-93, et suite à une suggestion de la Section Maritimes, nous avons annoncé un programme incitatif de recrutement de trois membres ce qui donnait droit à une annulation des frais pour le membre qui y participait. Ce programme incitatif, en plus des dépliants et de l'affiche devrait donner des résultats au cours de 1993-94.

\section{Forestry Chronicle}

Le personnel du Forestry Chronicle (Jim Cayford et Darwin Burgess, éditeurs, ainsi que Tim Fenton, directeur de la production) constitue le même groupe depuis sa mise en place en 1990-91. Leur travail poursuit son évolution et s'améliorer avec le temps. Leurs efforts deviennent l'évidence même en fonction de la demande constante des auteurs pour publier leurs articles, ce qui entraîne des revenus intéressants en terme de frais par pages et de tirés à part, des revenus appréciables à partir de la publicité, d'excellents commentaires et analyses de la part des mem- 
produced on a monthly basis in 1992-93. Several sections copy the Update and send it to each member and our corporate members find the Update an excellent way to keep abreast of forestry news across the country.

The Annual Report appeared in the December 1992 issue of The Forestry Chronicle and was not produced seperately, as was done in 1991-92.

Two issues of Forestry Dialogue/Forestier were produced in 1992-93. These publications, for federal politicians, covered the topics of Old Growth (December 1992), and National Forest Week (May 1993).

The Executive Committee, in response to a resolution at the 1992 annual Meeting, produced a paper on the need for better information about inventory and growth and yield. This paper was sent to Ministers responsible for Forestry as well as those in other portfolios which benefit from revenues generated from the forest. The other Ministers included Health, Education, Tourism, Indian Affairs, Justice, Revenue and others. The paper was also sent to the major media outlets across Canada.

\section{Awards}

This is the fourth year since we initiated the Tree of Life Award, for presentation by the Sections. CIF/IFC presented two hundred and ninety-two forestry rings to graduates at the seven forestry schools. Twenty-four Gold Medals were presented as well as the Schlich Award, and three members were admitted to the Golden Year Club (50 years of membership in CIF/IFC). At the Annual Meeting, The Forestry Achievement and the Forestry Scientific Achievement Awards will be presented.

\section{Annual Meetings}

The 1992 Annual Meeting was held in Vancouver and the theme was "Forestry: The Cornerstone of Canadian Society". As I mentioned earlier, the meeting enjoyed success both from a technical and a financial perspective.

The 1993 Annual Meeting was organized jointly by CIF/IFC and the Quebec Order of Forest Engineers. The 1994 meeting is being organized jointly with the Society of American Foresters and will be held in Anchorage, Alaska. The 1995 meeting will be in Halifax and 1996 will be in Thunder Bay.

\section{Executive Committee}

Just prior to the Annual meeting, the executive met in Vancouver on September 17, the Executive Committee met in Vancouver on September 24 to plan the activities and schedule for the balance of 1992-93. They met again in February 1993 in Fredericton and in May 1993 in Ottawa. Conference calls were held in October and December 1992 and in January, March, June and July and August 1993. I prepared agendas, notes for the meetings, minutes and follow up on items raised at each meeting and conference call. All minutes were circulated to each Section.

\section{Special Meetings}

The CIF/IFC is in partnership with Maclean Hunter and the Canadian Silviculture Association in organizing the second National Silviculture Conference in midSeptember.

Our President is currently Chair of the CFPFA. A meet- bres, des annonceurs et des organismes externes. Malgré le fait que le coût nets du Forestry Chronicle ont été légèrement supérieurs en 1992-93 à ce qu'ils ont été en 1991-92, il n'en demeure pas moins que le coût pour chaque membre pour recevoir cette remarquable publication est très abordable.

\section{Autres publications}

L'Information forestière/Forestry Update a été à nouveau publiée mensuellement en 1992-93. Certaines sections font des copies du bulletin et l'acheminent à chacun de leurs membres. Les membres corporatifs considèrent que le bulletin est un excellent moyen de demeurer à jour au niveau de l'information forestière de tout le pays.

Le rapport annuel a été publié dans l'édition de décembre 1992 du Forestry Chronicle. Il n'a pas été publié individuellement comme ce fut le cas en 1991-92.

Deux numéros du Forestry Dialogue Forestier ont été publiés en 1992-93. Ces publications, destinées aux politiciens fédéraux, couvaient les vieilles forets (dècembre 1992) et la semaine national des forêts (mai 1993).

Le comité exécutif, en réponse à une résolution adoptée à l'assemblée annuelle, a produit un mémoire faisant référence à la nécessité d'avoir une meilleure information sur les inventaires, la croissance et le rendement.Ce mémoire a été remis aux ministres responsables des forêts ainsi qu'à ceux dont les porte-feuilles tirent bénéfices des revenus générés par les forêts. Ces ministres comprenaient la Santé, l'Éducation, le Tourisme, les Affaires indiennes, la Justice, le Revenu et quelques autres ministères. Le mémoire a été également distribué aux principales sources d'information des médias au Canada.

\section{Prix}

Il s'agit de la quatrième année d'existence du prix de l'Arbre de la vie qui est remis par les sections. L'IFC/CIF a remis deux cent quatre vingt douze joncs de forestiers aux gradués des sept facultés de foresterie. Vingt-quatre médailles d'or ont été présentées en plus du prix Schlich, et trois membres sont devenus des jubilaires (50 ans à titre de membre de l'IFC/CIF). Au cours de l'assemblée annuelle, le prix pour une réalisation exceptionnelle en foresterie et celui en recherche forestière seront remis à leur titulaires.

\section{Assemblées annuelles}

L'assemblée annuelle 1992 a eu lieu à Vancouver sous le thème: "La foresterie: La pierre angulaire de la société canadienne". Tel que mentionné précédemment, l'assemblée a été un succès tant au plan technique que financier.

L'assemblée annuelle 1993 a été organisée conjointement par l'IFC/CIF et l'ordre des ingénieurs forestiers du Québec. L'assemblée annuelle 1994 est organisée conjointement avec la Société of American Foresters et aura lieu à Anchorage en Alaska. L'assemblée annuelle 1995 aura lieu à Halifax et celle de 1996, à Thunder Bay.

\section{Comité exécutif}

Le comité exécutif s'est réuni à Vancouver le 17 septembre, tout juste avant le début de l'assemblée annuelle, puis le 24 septembre afin de préparer les activités et les inscrire au calendrier pour le reste de l'année 1992-93. Le comité s'est réuni à nouveau en février 1993 à Frédéricton et en 
ing was held in October 1992, and a conference call was organized in June 1993. The October meeting was organized to discuss Codes of Practice and the June conference call was to discuss the federal role in forestry and forestry agreements.

\section{Communication and Liaison}

The Executive Committee maintain regular contact with the Institute through meetings (five in 1992-93) and conference calls (seven in 1992-93), and they also receive weekly mailings from the National Office and the President usually gets two or three calls a week.

Sections receive monthly mailings and several phone calls and I was able to meet seven sections in 1992-93.

There has been frequent contact with the federal Forestry Minister and the opposition forestry critics. CIF/IFC was asked to provide input into the next State of the Environment Report and we proposed several forestry questions for the Conservative Leadership Debates. The CIF/IFC co-hosted a reception on Parliament Hill with the Speaker of the House of Commons. Over 35 MPs were in attendance and the Speaker provided an excellent talk in support of CIF/IFC activities. The Executive committee then presented the Honourable John Fraser with Honourary CIF/IFC membership.

The CIF/IFC wrote to each of the leaders of the federal political parties and asked for responses to questions on Forestry at the federal level; the responses were printed in the October issue of The Forestry Chronicle.

\section{Administration}

Regular membership updates are being sent to the sections and we continue to strive to improve our information exchange. Our membership clerk, Mrs. Cherry Maxwell recently celebrated her first anniversary with CIF/IFC and is doing very well with all aspects of the operation of the Institute.

I must thank both Denise Trepanier, our Office Manager, and Cherry Maxwell, our membership clerk, for their constant support, good humour and willingness to tackle any and all challenges. I also want to thank Tim Fenton, Darwin Burgess and Jim Cayford for their continuing excellent efforts and constant improvements to The Forestry Chronicle. I think the CIF/IFC continues to be well served by this most dedicated group.

\section{C.A. Lee, R.P.F. Executive Director}

mai 1993 à Ottawa. Des appels conférences ont eu lieu en octobre et décembre 1992, ainsi qu'en janvier, mars, juin, juillet et août 1993. J'ai préparé les ordres du jour, les documents d'information pour ces réunions ainsi que leurs procès verbaux, puis assuré le suivi des points soulevés lors de chacune de ces réunions ou de ces appels conférences. Les procès verbaux de toutes ces réunions ont été distribués aux sections.

\section{Evénements spéciaux}

L'IFC/CIF a collaboré avec Maclean Hunter et l'Association canadienne de sylviculture pour l'organisation de la deuxième conférence sur la sylviculture qui a lieu à la mi-septembre 1993.

Notre président est actuellement président de la FCAPF. Une rencontre a eu lieu en octobre 1992, ainsi qu'un appel conférence en juin 1993. La rencontre d'octobre a porté sur les Codes de pratiques et l'appel conférence a permis de discuter du rôle du fédéral en foresterie et dans les ententes de mise en valeur des ressources forestières.

\section{Communication et liaison}

Le comité exécutif est demeuré régulièrement en contact avec l'Institut par l'entremise de réunions (cinq en 199293) et d'appels conférences (sept au cours de la même période), en plus de recevoir chaque semaine du courrier en provenance du siège social. Le président reçoit habituellement de deux à trois appels téléphonique par semaine.

Les sections reçoivent à tout les mois du courrier ainsi que plusieurs coup de téléphone. J'ai été en mesure de visiter sept sections en 1992-93.

De fréquents contacts ont été établis avec le ministre fédéral des Forêts ainsi qu'avec les critiques de l'Opposition. On a demandé à l'IFC/CIF de proposer quelques éléments à ajouter au prochain Rapport sur l'état de l'environnement et nous avons acheminé quelques questions reliées à la foresterie lors des débats entourant la course au leadership du Parti Conservateur. L'Institut a organisé conjointement avec le Président de la Chambre des Communes une réception sur la Colline parlementaire. Plus de 35 députés fédéraux y ont participé et le Président de la Chambre en a profité pour donner une excellente allocution plaidant pour plus de support des activités de l'IFC/CIF. Le Comité exécutif a présenté par la suite un certificat de membre honoraire de l'Institut à l'Honorable John Fraser.

\section{Administration}

Des mises à jour de la liste des membres sont remises régulièrement aux sections et nous cherchons par tous les moyens à améliorer nos échanges d'information. Notre responsable des membres, Mme Cherry Maxwell a célébré dernièrement sa première année avec l'Institut et poursuit son excellent travail sur tous les aspects des opérations de l'Institut.

Je dois remercier Mme Denise Trepanier, notre secrétaire administrative ainsi que Mme Cherry Maxwell, notre responsable des membres, pour leur support continu, leur bonne humeur et leur volonté de résoudre tous les défits qu'il nous faut relever. J'aimerais remercier également Tim Fenton, Darwin Burgess et Jim Cayford pour leurs efforts soutenus et leurs améliorations constantes du Chronicle. J'estime que l'IFC/CIF est très bien servi par ce groupe de personnes consciencieuses. 


\section{The Forestry Chronicle Annual Report, 1992-93}

During the fiscal year, six issues of The Forestry Chronicle were published - Numbers 4-6 of Volume 68 and Numbers 1-3 of Volume 69. The Forestry Chronicle staff were the same as in the previous year with J.H. Cayford and D.M. Burgess as Co-editors and T. Fenton as Production Manager.

During the year The Forestry Chronicle revenues were $\$ 113,879$ and expenditures $\$ 142,958$, resulting in a net cost to the Institute of about $\$ 29,000$, a little more than $\$ 10$ per member. This net cost was nearly triple that of 19911992 , primarily because of lower reprint sales $(\$ 12,000)$ and less advertising revenue $(\$ 7,000)$. Net costs were only slightly higher than those of 1990-91 $(\$ 23,000)$.

The six issues contained 776 pages distributed proportionally as follows:

Professional articles

Scientific and Technical articles $\quad 15 \%$

Special Features

$19 \%$

News and Views — including President's Column \& Editorial

Institute Affairs - including Annual Meeting Report \& By-Laws

University and Technical School News $\quad 5 \%$

Meetings

Publications

Book Reviews

Obituaries

Other- including advertising

Special features published during the year were as follows: October 1992 - Biodiversity FRACC Annual Report

December 1992 - Biodiversity Research FRACC Research Priorities

April $1993 \quad$ - Pathology Research International Forestry Research

June 1993 - Petawawa National Forestry Institute Anniversary

Forest Pathology Research

Minor changes in format, layout and content were made during the year. These included changes in headings, more use of colour sections, introduction of news section for technical schools, and increased meeting coverage including the United Nations Conference on Environment and
Development (UNCED), the CIF/IFC Annual Meeting, the Annual Meeting of the Woodlands Section of the Canadian Pulp and Paper Association and the IUFRO Centennial Meeting.

During the year news was published for 16 sections, the same as the previous year. Most of this was contributed, but some was extracted from newsletters and other documents. The contributions from the Maritime Section (Bob Spurway), the Orleans Section (Jean-Pierre Dansereau, Marie Coyea and Patrick Beauchesne), the Central Ontario Section (Tim Lynham), the Rocky Mountain Section (Gordon Brown) and the Vancouver Island Section (David Carson) have been outstanding and are much appreciated.

During the period, 42 scientific and technical manuscripts were received: Two were published, 17 have been approved for publication, 13 are under review and 10 were rejected. During this same period 13 professional articles were received; six have been published, four have been approved, two are under review and one has been rejected.

Plans for 1993-94 include publication of the program and abstracts for the 1993 Silviculture Conference, the papers presented at the Petawawa Red and White Pine Symposium, a series of papers on Community Forestry, and the papers on Biomass Production presented at a joint meeting of the International Poplar Commission and the International Energy Agency.

\section{J.H. Cayford \\ D.M. Burgess \\ T. Fenton}

Comparison of the contents of The Forestry Chronicle fiscal years 1988-89, 1989-90, 1990-91, 1991-92, 1992-93

\begin{tabular}{lrrrrr}
\hline & $1988-89$ & $1989-90$ & $1990-91$ & $1991-92$ & $1992-93$ \\
\hline $\begin{array}{l}\text { No. of professional } \\
\text { articles }\end{array}$ & 29 & 23 & 26 & 21 & 23 \\
$\begin{array}{l}\text { Pages of professional } \\
\quad \text { articles }\end{array}$ & 116 & 126 & 117 & 116 & 129 \\
$\begin{array}{l}\text { No. of scientific and } \\
\text { technical articles }\end{array}$ & 20 & 31 & 28 & 11 & 17 \\
$\begin{array}{l}\text { Pages of scientific and } \\
\quad \text { technical articles }\end{array}$ & 121 & 195 & 152 & 106 & 117 \\
$\begin{array}{l}\text { Pages devoted to } \\
\quad \text { symposia }\end{array}$ & 0 & 0 & 69 & 211 & 147 \\
$\begin{array}{l}\text { Pages devoted to other } \\
\quad \text { material }\end{array}$ & 251 & 279 & 310 & 424 & 383 \\
\begin{tabular}{l} 
Total Pages \\
\hline
\end{tabular} & 486 & 600 & 648 & 864 & 776 \\
\hline
\end{tabular}

\section{Report of The Finance Committee for Fiscal Year 1992-93}

\section{Highlights of the 1992-93 fiscal year General}

After serving on the Finance Committee for several years, I took over as Chair in 1992-93. Other members are Jim Marshall, Don Lockhart and Chris Lee. The Committee met six times in 1992-93 to discuss quarterly statements and make recommendations to the Executive on items such as membership promotions, the Directors meeting in Alaska and other items.
The attached table shows our year end position for 19911992 and 1992-93 and includes a budget for 1993-94 and a draft budget for 1994-95.

\section{Revenues 1992-93}

Revenue from members' dues is about $\$ 10,000$ less than budgeted and about $\$ 10,000$ less than dues received in 1992-92. Interest income is also much lower than budgeted 
at $\$ 2,000$ vs a budgeted figure of $\$ 5,000$. The brightest spot on the revenue side is the 1992 Annual Meeting which generated $\$ 16,000$ for the National Office from an overall surplus of about $\$ 24,000$. This success results in the Institute having a small surplus of \$3,000 in 1992-93.

\section{Expenses 1992-93}

The Annual Meeting expenses were almost $\$ 3,000$ more than budgeted due mainly to the travel costs.

\begin{tabular}{|c|c|c|c|c|}
\hline \multicolumn{5}{|c|}{ Proposed Budget 1993-94 } \\
\hline & 1991-92 & $1992-93$ & $\begin{array}{r}1993-94 \\
\text { budget }\end{array}$ & $\begin{array}{r}1994-95 \\
\text { budget }\end{array}$ \\
\hline \multicolumn{5}{|l|}{ Revenues } \\
\hline Memb. Dues & 214,266 & 205,600 & 206,000 & 210,000 \\
\hline Sustaining & 17,600 & 17,505 & 20,000 & 22,000 \\
\hline Interest & 5,198 & 5,798 & 5,500 & 5,500 \\
\hline Life Ins. & 1,179 & 1,812 & 1,800 & 1,800 \\
\hline Misc. Sales & 2,336 & 7,900 & 7,000 & 5,000 \\
\hline GST & 5,000 & 12,000 & 12,000 & 12,000 \\
\hline AGM & 0 & 16,800 & 2,000 & 10,000 \\
\hline Silv. Conf. & 0 & 0 & 5,000 & 0 \\
\hline TOTAL & 245,549 & 263,415 & 259,300 & 266,300 \\
\hline \multicolumn{5}{|l|}{ Expenses } \\
\hline $\mathrm{AGM}$ & 29,253 & 9,971 & 9,000 & 10,000 \\
\hline Salaries & 104,649 & 104,446 & 106,000 & 108,000 \\
\hline Travel: EC & 3,467 & 3,019 & 4,500 & 5,000 \\
\hline ED & 7,085 & 5,211 & 6,000 & 6,000 \\
\hline Dir & 6,959 & 6,703 & 8,000 & 12,000 \\
\hline Rent & 19,134 & 19,435 & 19,500 & 12,000 \\
\hline Hosp. & 1,393 & 2,060 & 2,000 & 2,000 \\
\hline Trans. & 2,937 & 2,380 & 2,400 & 2,400 \\
\hline Off Ex \& Sup & 17,900 & 18,115 & 18,000 & 18,000 \\
\hline Computer & 2,018 & 528 & 2,000 & 500 \\
\hline Mail: Office & 6,412 & 6,000 & 7,000 & 7,000 \\
\hline Memb. & 3,760 & 1,930 & 2,000 & 2,000 \\
\hline Courier & 0 & 0 & 1,500 & 1,500 \\
\hline Accred. & 2,000 & 6,437 & 4,000 & 4,000 \\
\hline Ann. Report & 11,478 & 0 & 0 & 0 \\
\hline Audit & 4,260 & 4,822 & 4,500 & 4,500 \\
\hline Awards & 11,089 & 10,994 & 11,000 & 11,000 \\
\hline Tel. & 6,524 & 7,516 & 7,500 & 8,000 \\
\hline Printing & 6,173 & 2,532 & 7,000 & 3,000 \\
\hline Student Fund & 0 & 0 & 2,000 & 3,500 \\
\hline Bank & 0 & 0 & 1,000 & 1,000 \\
\hline GST & 5,000 & 12,000 & 12,000 & 12,000 \\
\hline Misc. & 4,225 & 5,155 & 5,000 & 7,000 \\
\hline For. Chron. & 11,218 & 29,079 & 25,000 & 19,000 \\
\hline TOTAL & 266,934 & 260,133 & 266,900 & 259,400 \\
\hline NET BALANCE & $-21,385$ & 3,282 & $-7,600$ & 6,900 \\
\hline \multicolumn{5}{|c|}{ Proposed budget, The Forestry Chronicle } \\
\hline & $1991-92$ & $1992-93$ & $\begin{array}{r}1993-94 \\
\text { budget }\end{array}$ & $\begin{array}{r}1994-95 \\
\text { budget }\end{array}$ \\
\hline \multicolumn{5}{|l|}{ Revenues } \\
\hline Advert & 38,875 & 29,995 & 31,500 & 33,000 \\
\hline Page Charges & 41,249 & 37,156 & 37,000 & 40,000 \\
\hline Reprints & 27,828 & 15,242 & 16,000 & 18,000 \\
\hline Subs. & 34,824 & 31,486 & 32,000 & 35,000 \\
\hline TOTAL & 140,776 & 113,879 & 116,500 & 126,000 \\
\hline \multicolumn{5}{|l|}{ Expenses } \\
\hline Editors & 7,021 & 10,045 & 12,000 & 13,000 \\
\hline Production & 10,642 & 9,735 & 10,000 & 10,500 \\
\hline Printing & 99,998 & 91,894 & 88,000 & 88,000 \\
\hline Mailing & 17,063 & 18,362 & 19,000 & 20,000 \\
\hline Reprints & 14,748 & 8,457 & 8,500 & 9,000 \\
\hline Misc. & 3,172 & 4,465 & 4,000 & 4,500 \\
\hline TOTAL & 152,644 & 142,958 & 141,500 & 145,000 \\
\hline NET BALANCE & 11,218 & 29,079 & 25,000 & 19,000 \\
\hline
\end{tabular}

Salaries are under budget as are travel costs for the Executive, Executive Director and the Directors. Most other items are close to budget except for Printing and Miscellaneous. Miscellaneous includes bank charges (larger this year due to Visa and Mastercard), courier, subscriptions and memberships, certificates and a large purchase of jackets, mugs and books, etc. for resale. The Miscellaneous heading has been subdivided to give more detail in the draft budget for 1993-94. Printing was significantly under budget because of late billing and carry-over for a poster and brochures.

\section{The Forestry Chronicle 1992-93}

\section{Revenues}

The budget for The Forestry Chronicle for 1992-93 was based on the performance in 1991-92. Closer analysis of the 1991-92 figures revealed that several large reprint orders and feature issues resulted in greater than normal revenue from page charges and reprints. The feature issues also contributed to the strong performance in advertising revenues in 1991-92. Without these large reprint orders and very good advertising sales, the Chronicle revenue in $1992-93$ is only $\$ 113,900$ rather than the budgeted $\$ 140,000$.

\section{Expenses}

With fewer reprint orders, reprint costs are also under budget as are printing and mailing costs. The net cost of The Forestry Chronicle is therefore over the budget, at $\$ 29,000$ vs $\$ 15,000$ budget.

Given the strong influence The Forestry Chronicle has on the overall Institute budget, the Finance Committee took a close look at the breakdown of revenue generating pages (scientific and technical articles) vs non-revenue generating pages (news \& views, Institute Affairs, book reviews, etc.).

The Following shows revenue and non-revenue pages over the last few years and the ratio between the two:

\begin{tabular}{lccc}
\hline Year & Total Pages & Revenue Pages & Ratio \\
\hline $92-93$ (5 issues) & 643 & 296 & .46 \\
$91 / 92$ & 864 & 440 & .51 \\
$90 / 91$ & 648 & 338 & .52 \\
$89 / 90$ & 600 & 321 & .535 \\
$88 / 89$ & 488 & 237 & .486
\end{tabular}

It becomes a matter of concern when the ratio of revenue to non-revenue pages is below .50 since revenues decrease while printing costs increase. This is particularly true when total page numbers are high. The Finance Committee therefore recommends that the Executive Committee direct The Forestry Chronicle Editor to maintain fifty percent or greater of revenue generating pages for each future issue of The Forestry Chronicle.

\section{Budget for 1993-94}

The Institute is facing a bleak financial situation as membership slips and costs rise, albeit slowly. The draft budget for 1993-94 shows a deficit of \$7600. Achieving a 
good financial result at the Silviculture Conference planned for the fall of 1993 and at the Annual General Meeting will be important. In addition it will be important to hold the net costs of The Forestry Chronicle to $\$ 25,000$. Other economies will be required as well. The travel budget has been reduced from previous years, salaries and benefits are up slightly and tight budgets have been struck in several other areas. Membership dues have been held constant for two years (1991-92 and 1993-94). The Institute experienced a severe financial crisis in the early 1980 s when deficits soared to over $\$ 30,000$. This was due in part to a reluctance to increase the membership dues in previous years. The Institute must be careful to avoid the same trap in the 1990s. The dues schedule for 1994-95 will be set at the 1993 Annual Meeting. The Finance Committee recommends a modest increase of 2 or 3 percent which is in keeping with inflation in recent times and should not seriously affect members and membership. This will generate an additional $\$ 4,000$ to $\$ 6,000$ in revenue and reduce Institute exposure to financial uncertainty caused by relying on surpluses from events like the upcoming Silviculture Conference or the Annual Meetings. Conferences and Annual Meetings can lose money and should this happen, the results would be very serious indeed.

\section{Conclusion}

I wish to thank the members of the Finance Committee for their work 1992-93. Jim Marshall who has served the Committee and the Institute well for many years is stepping down this year. I want to express a special thanks to him for his thoughtful input to committee deliberation. If you have ideas about a worthy successor preferably in Ottawa area, please make them known to the Institute Executive.

\section{R.J. Bourchier, R.P.F. Chairman}

\section{Auditors' Report}

To the Members of the Canadian Institute of Forestry Institut Forestier du Canada

We have audited the balance sheet of the Canadian Institute of Forestry - Institut Forestier du Canada as at June 30, 1993 and the statement of operations and deficit for the year then ended. These financial statements are the responsibility of the Institute's management. Our responsibility is to express an opinion on these financial statements based on our audit.

We conducted our audit in accordance with generally accepted auditing standards. Those standards require that we plan and perform an audit to obtain reasonable assurance whether the financial statements are free of material misstatement. An audit includes examining, on a test basis, evidence supporting the amounts and disclosures in the financial statements. An audit also includes assessing the accounting principles used and significant estimates made by management, as well as evaluating the overall financial statement presentation.
In our opinion, these financial statements present fairly in all material respects, the financial position of the Institute as at June 30, 1993 and the results of its operations for the year then ended in accordance with generally accepted accounting principles.

OTTAWA, August 16, 1993

Cook, Perry, Sewell \& Co. Chartered Accountants

\section{Canadian Institute of Forestry - Institut Forestier du Canada \\ Balance Sheet - June 30, 1993 \\ Assets

$\begin{array}{lrr}\text { Current Assets } & \mathbf{1 9 9 3} & 1992 \\ \begin{array}{l}\text { Cash and term deposits } \\ \text { Accrued interest receivable }\end{array} & \$ 113,475 & \$ 95,415 \\ \text { Accounts receivable } & - & 644 \\ \begin{array}{l}\text { Capital Assets } \\ \text { Office furniture and equipment }\end{array} & \underline{34,596} & \frac{26,063}{122,122} \\ & \underline{148,071} & \underline{148,072} \\ \end{array}$

Current Liabilities

Accounts payable and accrued liabilities

Dues and subscriptions received in advance

Deferred revenue

(Deficit)

$\$ 34,055$

$\$ 24,597$

108,174

9,371

$\frac{9,371}{151,600}$

$\frac{(3,528)}{\$ 148,072}$

93,572

10,764

128,933

$(6,810)$

$\underline{\$ 148,072}$

$\$ 122,123$

Canadian Institute of Forestry - Institut Forestier du Canada

Statement of Operations and Surplus (Deficit) for the Year Ended June 30, 1993

\begin{tabular}{lrr}
\hline Revenues & $\mathbf{1 9 9 3}$ & $\mathbf{1 9 9 2}$ \\
China exchange - CIDA & & \\
Forestry Chronicle (per schedule) & 113,879 & 17,707 \\
Group insurance commission & 1,812 & 141,426 \\
Interest on investments & 5,798 & 1,179 \\
Members' dues & 219,105 & 5,198 \\
Miscellaneous & 7,900 & 231,866 \\
& 348,494 & 2,336 \\
Expenditures & & 399,712 \\
Administration & & \\
Annual meeting & $5,029)$ & 29,253 \\
Annual report & - & 11,478 \\
China exchange-CIDA & - & 17,707 \\
Computer services & 528 & 2,018 \\
Hospitality & 2,060 & 1,393 \\
Legal and audit & 4,822 & 4,260 \\
Mailing to members & - & 3,760 \\
Medals, caps, rings and awards & 10,994 & 11,089 \\
Miscellaneous expenses & 5,155 & 4,225 \\
National accreditation expense & 6,437 & 2,000 \\
Office expenses & 16,975 & 15,802 \\
Office supplies & 1,140 & 2,098 \\
Postage & 7,930 & 6,412 \\
Printing & 2,532 & 6,173 \\
Rent & 19,435 & 19,134 \\
Telephone & 7,516 & 6,524 \\
Translation & 2,380 & 2,937 \\
Forestry Chronicle (per schedule) & $\underline{82,875}$ & 146,263 \\
Travel & $\underline{142,958}$ & $\underline{152,644}$ \\
Directors & & \\
Executive & 6,703 & 6,959 \\
Executive-Director & 3,019 & 3,467 \\
Total expenditures - carried forward & $\$ 240,766$ & 7,085 \\
\hline & & 17,511 \\
& 5316,418 \\
\hline
\end{tabular}


Canadian Institute of Forestry - Institut Forestier du Canada

Statement of Operations and Surplus (Deficit) for the Year Ended June 30, 1993

\begin{tabular}{|c|c|c|}
\hline & 1993 & 1992 \\
\hline Total expenditures - brought foward & $\$ 240,766$ & $\$ 316,418$ \\
\hline $\begin{array}{l}\text { Excess of total revenues over non- } \\
\text { salary expenditures }\end{array}$ & 107,728 & 83,294 \\
\hline \multicolumn{3}{|l|}{ Salaries } \\
\hline Casual help & 14,670 & 12,908 \\
\hline \multirow[t]{2}{*}{ Office } & 89,776 & 91,741 \\
\hline & $\overline{104,446}$ & 104,649 \\
\hline \multicolumn{3}{|l|}{$\begin{array}{l}\text { Excess of total revenues over total } \\
\text { expenditures (total expenditures }\end{array}$} \\
\hline $\begin{array}{l}\text { over total revenues) for the year } \\
\text { Surplus (deficit) - beginning of year }\end{array}$ & $\begin{array}{r}3,282 \\
(6,810) \\
\end{array}$ & $\begin{array}{r}(21,355) \\
14,545\end{array}$ \\
\hline (Deficit) - end of year & $\$(3,528)$ & $\$(6,810)$ \\
\hline \multicolumn{3}{|c|}{$\begin{array}{l}\text { Canadian Institute of Forestry - Institut Forestier du } \\
\text { Canada }\end{array}$} \\
\hline \multicolumn{3}{|c|}{$\begin{array}{c}\text { Schedule of Forestry Chronicle Revenues and } \\
\text { Expenditures } \\
\text { for the Year Ended June 30, } 1993\end{array}$} \\
\hline & 1993 & 1992 \\
\hline \multicolumn{3}{|l|}{ Revenues } \\
\hline Advertising & $\$ 29,995$ & $\$ 36,875$ \\
\hline Colour productions & 897 & 1,650 \\
\hline Page charges & 36,259 & 40,249 \\
\hline Reprints & 15,242 & 27,828 \\
\hline \multirow[t]{2}{*}{ Subscriptions and sales } & 31,486 & 34,824 \\
\hline & $\$ 113,879$ & $\$ 141,426$ \\
\hline \multicolumn{3}{|l|}{ Expenditures } \\
\hline Editing & $\$ 10,045$ & $\$ 7,021$ \\
\hline Mailing & 18,362 & 17,063 \\
\hline Printing & 91,894 & 99,998 \\
\hline Production & 9,735 & 10,642 \\
\hline Reprints & 8,457 & 14,748 \\
\hline \multirow[t]{2}{*}{ Miscellaneous } & 4,465 & 3,172 \\
\hline & $\$ 142,958$ & $\$ 152,644$ \\
\hline $\begin{array}{l}\text { Net cost of operating the } \\
\text { Forestry Chronicle }\end{array}$ & $\$ 29,079$ & \$ 11,218 \\
\hline
\end{tabular}

Notes to the Financial Statements , June 30, 1993

1. Significant accounting policy

Capital assets

Purchases of office furniture and equipment are charged directly to expenditures. A nominal value of $\$ 1$ is carried on the balance sheet in recognition of the existence of such assets.

\section{Contractual obligation}

The Institute leases office space at a monthly rate of $\$ 1,344$ under a lease agreement which expires in May 1994.

\section{Other financial information}

a) The Institute, incorporated Federally as a corporation without share capital, qualifies as a non- profit organization for an exemption from income tax under Federal and Ontario legislation.

b) Certain of the comparative figures have been restated to conform with the presentation adopted in the current year.
Forestry Awareness in Canada Trust Committee

\section{Introduction}

This year was sluggish...much like the economy.

We increased the representation on the Board and we were actively involved in a contemporary education project.

The 1992-93 FACT Board is:

Glen Swant - President

Ernie Heidersdorf - Trustee

Jim Kayll - Trustee

Chris Lee - Trustee and Secretary

Gerry Joudrey - Trustee

Vic Begrand - Trustee

Welcome Gerry and Vic.

\section{Applications for Project Assistance}

We received two proposals. One was funded and the other was not.

The following is a brief description of the project which was approved for funding.

Title: Taking School to the Woods - Shoreline Forest Resource Use Project

Section: Vancouver Island Section

Project Leader: Davis Carson-CIF

Janet Morton - Shoreline Community School Association, Victoria, BC.

Description of Project: One hundred Grade 9 students examined a resource management issue (Walbran Watershed) from a variety of perspectives.

First, the teachers were given courses on forest use and management issues; then the students; then a series of four 2-day trips; then a summary presentation by the students on a plan for the Walbran Forest; followed by a critique by experts.

The education and scrutiny of the plans was performed by science teachers, local CIF members, Fletcher Challenge, MacMillan Bloedel, the Serria Club, the North Cowichan Municipality, and the Ministry of Forests.

The field trips were conducted using these groups too.

This project is particularly significant because for the first time a contentious forestry issue was researched and discussed in a balanced fashion. It removed most of the bias and presented the case as it should be...factual with all facets considered.

We did not approve a request to assist in publishing a National Forest Education catalogue. The request came from the Canadian Forestry Association.

\section{Summary}

Although there were few requests for funding, the one we approved is an excellent awareness project.

I would strongly recommend that each section do the same. Each section has a contentious issue, I am sure. Go through the same education process as the Victoria group. It is a perfect way to educate people on Forestry in the 1990s.

We welcome any and all projects in 1993-94. G.R.Swant August 27, 1993 
To the Trustees of the

\section{Auditors' Report}

\section{Forestry Awareness In Canada Trust}

We have audited the balance sheet of the Forestry Awareness In Canada Trust as at June 30, 1993 and the statement of operations and surplus for the year then ended. These financial statements are the responsibility of the Trust's management. Our responsibility is to express an opinion on these financial statements based on our audit.

We conducted our audit in accordance with generally accepted auditing standards. Those standards require that we plan and perform an audit to obtain reasonable assurance whether the financial statements are free of material misstatement. An audit includes examining, on a test basis, evidence supporting the amounts and disclosures in the financial statements. An audit also includes assessing the accounting principles used and significant estimates made by management, as well as evaluating the overall financial statement presentation.

In our opinion, these financial statements present fairly in all material respects, the financial position of the Trust as at June 30, 1993 and the results of its operations for the year then ended in accordance with generally accepted accounting principles.

OTTAWA, August 11, 1993

Cook, Perry, Sewall \& Co. Chartered Accountants

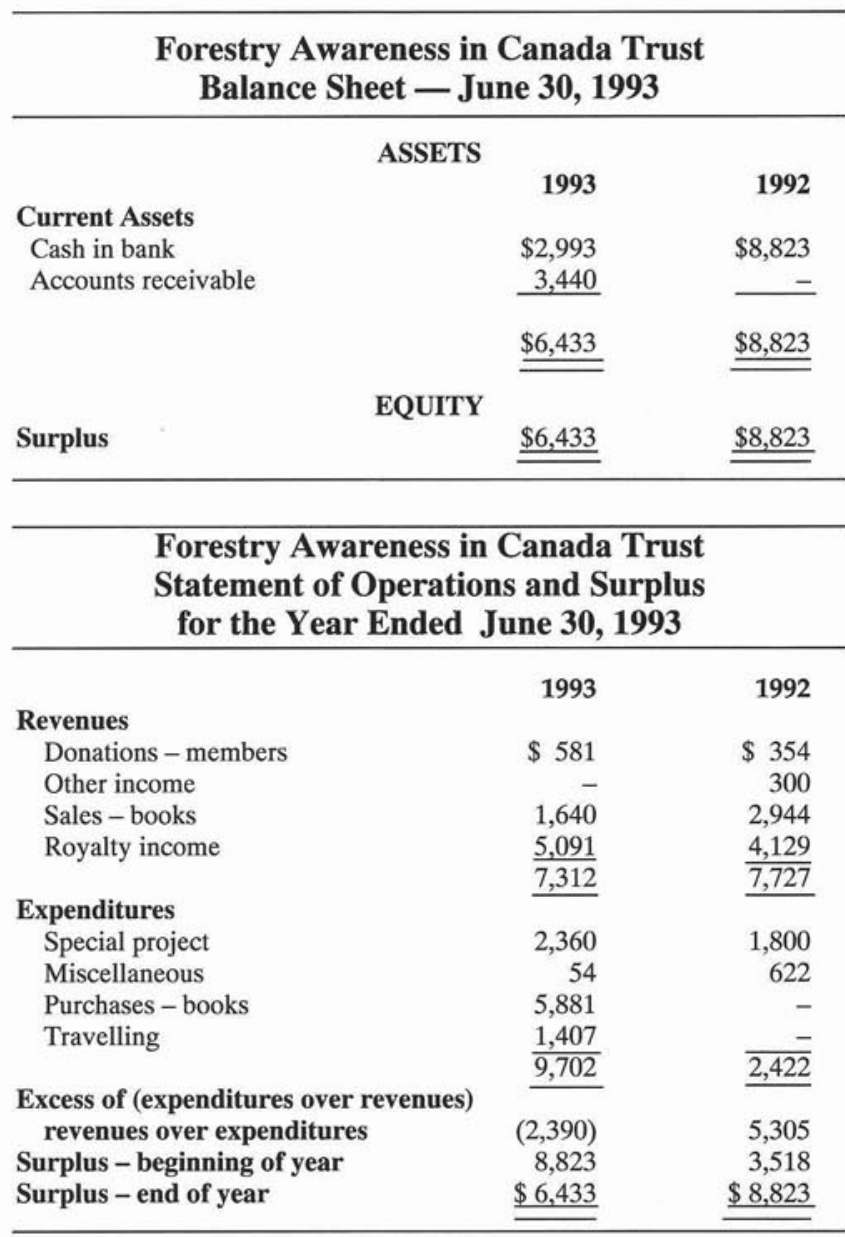

\section{National Committee Reports}

\section{Forest Science and Technology Board}

The Forest Science and Technology Board (FSTB) consists of the chairs of the various working group sections within the CIF/IFC. Its primary purpose is to provide technological advice to the CIF\IFC Council.

This year was a very quiet one for the Board. Organization of the technical sessions at the 1993 Annual Meeting, normally a responsibility of the Board, was handled by a local committee. The FSTB was represented on the planning committee by Dr. Pierre Bernier, past chair of the FSTB. Only a few items were passed to the Board members from the Council over the past year. These were able to be addressed by the Board members individually, for the most part.

Over the past year and a half, many of the Board members assisted in the preparation of position papers on a number of topics suggested by the CIFIFC Council. These position papers are intended to provide information on relevant technical topics within forestry, in a manner that may be understood by a non-specialist. Unfortunately, the position papers have evolved much more slowly than was originally planned. At the present time, the position papers that have been reviewed by the Council are being returned to the Board members responsible, with suggestions for changes made by various Council members. As chair of the FSTB, I intend to take a more active role in encouraging completion of the position papers over the next few months.

I wish to complete this report by thanking the members of the FSTB for the effort that they have extended to serving the CIF $\backslash$ IFC during their tenure on the Board. The work load is not usually heavy, but I know from personal experience that most members have very little extra time, outside of their other commitments, to devote to the Board's duties.

Peter L. Marshall Chair, FSTB

\section{Membership Committee}

The attached Table 1 provides a summary of membership from 1984 to 1993. As indicated, membership decreased in 1992-93 from 2356 to 2324 , a drop of $2 \%$ or 32 members. While this is not great, it is less of a decrease than we experienced in 1991-92, when we lost 57 members.

The most encouraging trend seen in Table 1 is that student membership is at 154 , the highest level in four years. It is hoped that the "Three for One", dues levels staying the same in 199394 as they were in 1992-93 and the brochure and poster effort will begin to increase our membership in 199394. Other ideas for increasing membership will be discussed at the Directors Meeting.

Corporate Sustaining Membership is at 53 up from 45 last year, while Individual Sustaining is at 62, up from 55 last year. 
Table 1. CIF/IFC Membership 1984-93

\begin{tabular}{lllllllllll}
\hline Membership & 1984 & 1985 & 1986 & 1987 & 1988 & 1989 & 1990 & 1991 & 1992 & $\mathbf{1 9 9 3}$ \\
\hline Active & - & 1842 & 1815 & 1578 & 1646 & 1711 & 1770 & 1922 & 1868 & $\mathbf{1 8 0 8}$ \\
Affiliate & - & 87 & 75 & 54 & 66 & 65 & - & - & - & - \\
Fellow & - & 31 & 31 & 29 & 31 & 32 & 30 & 29 & 32 & $\mathbf{2 8}$ \\
Honourary & - & 4 & 6 & 6 & 6 & 5 & 5 & 5 & 6 \\
Retired Paying & - & 112 & 119 & 136 & 147 & 161 & 164 & 195 & 213 & $\mathbf{2 2 3}$ \\
Ret. Non-paying & - & 116 & 116 & 110 & 116 & 126 & 129 & 118 & 114 & $\mathbf{1 0 7}$ \\
Students & - & 171 & 148 & 74 & 195 & 164 & 136 & 129 & 122 \\
Non-members $^{1}$ & - & - & - & 129 & 143 & 83 & 26 & 15 & 1 \\
Total & 2435 & 2363 & 2310 & 2116 & 2350 & 2347 & 2260 & 2413 & 2356 & $\mathbf{2 3 2 4}$ \\
\hline
\end{tabular}

${ }^{1}$ Members of Alberta Registered Professional Foresters Association who have not joined the Institute.

\begin{tabular}{|c|c|c|c|c|c|c|}
\hline Section & $\begin{array}{c}\text { Members } \\
1991-92\end{array}$ & $\begin{array}{l}\text { Members } \\
\text { Removed }\end{array}$ & $\begin{array}{c}\text { New } \\
\text { Members }\end{array}$ & $\begin{array}{c}\text { Members } \\
1992-93 \\
\end{array}$ & $\begin{array}{c}\text { Net } \\
\text { Increase }\end{array}$ & $\begin{array}{l}\text { Percent } \\
\text { Inc/Dec }\end{array}$ \\
\hline $\mathrm{AL}$ & 56 & 7 & 2 & 51 & -5 & $(9.8)$ \\
\hline $\mathrm{CC}$ & 18 & 0 & 2 & 20 & 2 & 10.0 \\
\hline CR & 92 & 19 & 7 & 80 & -12 & (15.1) \\
\hline $\mathrm{CO}$ & 135 & 10 & 4 & 129 & -6 & $(4.6)$ \\
\hline $\mathrm{CH}$ & 62 & 9 & 6 & 59 & -3 & (5.1) \\
\hline LW & 40 & 4 & 7 & 43 & 3 & 7.0 \\
\hline MB & 46 & 0 & 3 & 49 & 3 & 6.1 \\
\hline MR & 152 & 12 & 10 & 150 & -2 & (1.3) \\
\hline ND & 54 & 0 & 7 & 61 & 7 & 11.5 \\
\hline NO & 18 & 0 & 1 & 19 & 1 & 5.3 \\
\hline NWO & 103 & 13 & 13 & 103 & 0 & 0 \\
\hline NS & 113 & 8 & 16 & 121 & 8 & 6.6 \\
\hline OK & 53 & 4 & 2 & 51 & -2 & (3.9) \\
\hline OR & 90 & 12 & 17 & 95 & 5 & 5.3 \\
\hline OV & 106 & 6 & 9 & 109 & 3 & 2.7 \\
\hline PA & 47 & 17 & 0 & 40 & -17 & $(56.7)$ \\
\hline RM & 458 & 15 & 37 & 480 & 22 & 4.6 \\
\hline SK & 44 & 0 & 2 & 46 & 2 & 4.3 \\
\hline $\mathrm{SN}$ & 22 & 3 & 9 & 28 & 6 & 21.4 \\
\hline SO & 153 & 9 & 8 & 152 & -1 & (0.1) \\
\hline VA & 265 & 27 & 8 & 246 & -19 & (7.7) \\
\hline VI & 176 & 19 & 3 & 160 & -16 & $(10.0)$ \\
\hline UN & 53 & 11 & 0 & 42 & -11 & (26.2) \\
\hline TOTAL & 2356 & 203 & 173 & 2324 & (32) & \\
\hline
\end{tabular}

The Recruiting prize for 1991-92 (based on the fiscal year July 1, 1992 to June 30,1993 ) is awarded to Skeena Section. Other Sections showing encouraging increases in membership include Cariboo Chilcotin, Newfoundland, and Lake of the Woods.

\section{C.A. Lee, R.P.F.}

\section{By-Laws and Rules and \\ Regulations Committee}

The By-laws Committee includes Brian Gilfillan (Vancouver), Tom Sifton (Fredericton) and Dr. Pierre Zundel (Edmundston). Several changes are proposed for 1993.

1. Dr. Doug Redmond noted that, despite the money and effort spent on various awards, there was no mention of them in the By-laws. It is therefore proposed that two new "objects" be added as follows:

To recognize the outstanding contributions made to forestry by members and non-members through a national awards program.

To recognize and welcome to the profession graduates from Canadian University Forestry Schools, through the presentation of forestry rings.

These would be added as No. 6 and 7 and the current object No. 6 would become No. 8 .
2. The first paragraph of the incorporation and objects refers to "carrying on in more than one province". Since Sections may be formed in the Territories, it is proposed to add "or Territory".

3. Object No. 2 mentions "Forestry, Forests and Forest Industry." In keeping with the current view of an expanded definition of forests, it is proposed that "Forests" be replaced by "Forest ecosystems".

4. In section 3.2.1, several science and social science programs are listed; however, Environment is not included, it is therefore proposed that the word "Environment" be added. 
5. Section 7.2.1.3 describes the requirement for budgets. The proposed change to this section reflects more accurately the current practice and the wording is proposed as follows: "an audited financial statement for the previous financial year and". Also proposed to be added "along with expenditures to date for the current financial year". The final part of section 7.2.1.3 would be deleted, as indicated.

6. At the 1992 Annual Meeting, the Saskatchewan Section voiced a concern that many foresters in Saskatchewan were CIF/IFC members but were not members of the Saskatchewan Section. They proposed a wording change for section 13.2 of the By-laws. Proposed wording to be added would be "Members should join the Section in which they work and reside".

7. Section 3. of the Rules and Regulations deals with Finances. Section 3.3.2 still contains the old description of how surplus funds from Annual Meetings are to be divided. The proposed wording change reflects the change in policy which was adopted by the Board of Directors at the 1991 Annual Meeting. The proposal is to delete " $\$ 1000$ of surplus plus $50 \%$ of the surplus between $\$ 1000$ and $\$ 3000$ plus $10 \%$ of the rest"; add " $\$ 3000 "$ "; add "will be divided so that $80 \%$ goes"; and add "and $20 \%$ goes to the Host Section", in the location indicated in section 3.3.2 of the Rules and Regulations.

8. Section 4.3.5 was written before an Accreditation process was in place. Since this is now the case, it is proposed that the word "Accredited" be added to recognize this process.

9. With the creation of the "Three for One" program to promote new memberships, it may be necessary to mention this type of waiver in section 4.5. Since this program is currently a trial only, no change to the Rules and Regulations is being proposed at this time.
Nominating Committee

The 1992-93 Nominating Committee consisted of A. Whidden (Chair) and C. Lee (Secretary). Hap Oldham was nominated First VicePresident and Steve Tolnai (Okanagan Section) was nominated for Second Vice-President.

The election results are as follows:

A.A. Rotherham - assumes the post

of Past President

P. Murphy - assumes the post of

President

H. Oldham - First Vice -President

by acclamation

S. Tolnai - Second Vice-President

by acclamation

\section{Awards Committee}

Chairman: A.A. Rotherham

Members: Executive Committee

Secretary: C.A. Lee

The Awards Committee is the Executive committee sitting as a special committee of the whole. Recipients for the Canadian Forestry Achievement Award, the Canadian Forestry Scientific Achievement Award and the International Forestry Achievement Award were considered and awards will be presented at the 1993 Annual Meeting. The Nominations for Fellow Memberships and Honourary membership were as follows:

1. Fellow - W. Ross Grinnell (Southern Ontario)

- Dr. R.J. (Bob) Bourchier

(Ottawa Valley)

2. Honourary - the Executive Committee has awarded an Honourary Membership to the Honourable John Fraser for his long term commitment and dedication to the cause of Forestry.

The Gold Medal Winners are as follows:

UBC

Alberta

Lakehead

Laval

Toronto

New Brunswick

Tahl D. Lunoch

S.Walkinshaw

Moncton

Mar Forest Ranger

West Viking

College
Abitibi-Temiscam

Chicoutimi

Baie-Comeau

Marie-France

Bellavance

Rimouski

François

Leblanc

Sainte-Foy

Saint-Félicien

Jérome Fontaine

Algonquin

John K. Akitis

Lakehead

Sault College

Joe Kennedy

Sir Sanford

Flemming

SIAST

For. Tech. Hinton

Valerie Latrille

Not awarded

Amber

Dereshkevich

BCIT David A.

Southam

New Caledonia

Patricia Berston

Malaspina

Selkirk

George Snyder

The Schlich Award Winner was from

Lakehead University.

Members admitted to the golden Year

Club in 1993:

Lloyd S. Hawboldt

Jack H. Hope

Donald W. MacLean

Foresters Rings were presented to two hundred and ninety-two graduating students including 7 from Moncton, 75 from Laval, 47 from UNB, 18 from University of Toronto, 17 from Lakehead, 46 from University of Alberta and 82 from UBC.

Tree of Life Awards were presented as follows:

Harry Struik

Central Ontario Section

Peter Jackson

Nova Scotia Section

A summary of Tree of Life Award winners on file at the National Office is attached.

The award for the Section obtaining the greatest percentage increase in membership is presented to Skeena Section who achieved a twenty-one percent increase in members.

C.A. Lee, R.P.F. August 5, 1993 
Tree of Life Award

Name

Jack Flowers

John McNicol

William H. Hendershot

Thom Erdel

Hank Blenis

G.E. Wellburn

Harry Pillar

Andrea Atkinson

E. Cladwell

Les Carlson

L. Otis

Bert Gayle

Larry Jago

Bob Haig

C.K. Smith

Wayne Brown

Peter Murphy

Jack Wright

\section{Recipients 1990/91}

Name

H.J. (Joe) O'Neill

Will Stiell

Don Grant

J.H.G. Smith

R.J.F Elder

J.D. MacArthur

Lorne Brace

Reginald Loomis

Web Webster

Recipients 1991/92

Name

Jim Clark

Dr. Bruce Dancik

Derek Brown

Bill Bourgeois

Art Walker

Noel Golder

Don Start

Frank Pendl

Peter Sanders

Ross Waldron

Boyd Brown

Carl Halland

Herb Bax

Al Todd

\section{Recipients 1992/93}

Name

Harry Struik

Peter Jackson

Section
NWO
NWO
CH
MR
MR
VI
VI
SK
OV
OV
OR
VA
CO
CO
MB
ND
RM
RM

Section

MR

$\mathrm{AL}$

VA

VA

VI

$\mathrm{CH}$

RM

RM

MB

$\begin{array}{ll}\text { Section } & \text { which twenty-two members partici- } \\ \text { RM } & \text { pated. Survey results were analyzed } \\ \text { RM } & \text { as the basis for discussion of future } \\ \text { ND } & \text { action. }\end{array}$

3. Member input via the workshop was synthesized to form a draft position statement, which was submittd to the FSTB and CFF Executive in the summer of 1993.

\section{Glen Blouin, Chair, \\ Forest Education Working Group}

\section{Forest Harvesting}

The Forest Harvesting Working Group sponsored a panel at the 1992 Annual Meeting in Vancouver. About twenty people attended. The panel consisted of Daniel Guimier, who reviewed FERIC's Eastern Division Research Program and Alex Sinclair, who reviewed FERIC's Western Division Research Program. A third speaker cancelled at the last minute.

Alex W.J. Sinclair, P. Eng., M.B.A. Manager, Western Division, FERIC

\section{Forest Hydrology}

During the 1992/93 fiscal year, the Forest Hydrology Working Group experienced two personnel changes. Barry Northey completed his term as Chairman. Ed McGurk, from the Southern Ontario Section, assumed the position of Chairman. Ed McGurk recruited Wayne Wasiliew, RPF, from the Interior British Columbia Section, as Vice-Chairman of the Group.

The Forest Hydrology Working Group has chosen to focus on "Urban Forest Hydrology" issues. As our communities expand, there appears to be more of an impact on the urban or fringe forest. There seems to be more forest hydrology research conducted on small, urban watersheds than on larger, forested watersheds bordered by harvesting areas. For this reason, we are hoping to prepare at least a few technical papers related to urban forest hydrology studies.

There is no opportunity for a technical session at the 1993 CIF conference in Montreal. The attendance of Canadian foresters at the 1994 CIF conference in Anchorage may be limited. Therefore, we are hoping to hold a technical session with at least a few papers or technical summaries at the 1995 CIF conference.

We were asked to develop a position on Forest Practice Guidelines for the CIF. A draft of these guidelines has been forwarded to Tony Rotherham. Additional comments have been received recently from a few Forest Hydrology Working Group members. These comments will be summarized and forwarded to Tony Rotherham.

The Forest Hydrology Working Group will be represented at the 1993 CIF Conference in Montreal.

Ed McGurk, Chairman

\section{Forest Management}

The principal activity of the Forest Management Working Group in $1992 / 93$ was the development of a position paper on Landscape Management. This paper was developed by a few selected members of the working group and was not reviewed by the group as a whole. 
The position paper is presently being revised based on comments provided by the Council and should be re-submitted to Council before the end of September.

The Chair handled a few specific requests from Council during the year. These were addressed by the Chair alone or by a small number of working group members who had some knowledge of the topic.

Plans for 1993/94 include re-establishing communications with the Forest Management Working Group membership. A letter explaining the intended purposes of the working group and a short questionnaire designed to solicit the topics of interest to the membership and the general level of interest will be prepared and distributed this fall. The results of this questionnaire will be distributed to the participants and hopefully will form the basis for a more active working group in future years.

Peter L. Marshall Chair, Forest Management Working Group

\section{Canadian Institute of Forestry/Institut Forestier du Canada 85th Annual General Meeting, September 29, 1993 Montréal, Québec}

\section{Minutes}

1.

Opening

President Rotherham opened the meeting at 13:30 and welcomed all delegates. He introduced Steve Tolnai, incoming Vice-President, and welcomed Past Presidents.

\section{Past Presidents}

Arden Whidden

J.R. Carrow

Claude Godbout

V.J. Nordin

J.H. Cayford

2.

Deceased Members

The President asked delegates to stand while he read the names of members deceased since the last Annual meeting. They are:

Peter Addison - SO. Ontario

C.R. Silversides - Ottawa Valley

K.C. Irving

Vladimir Krajina - Vancouver

J.D. Little - Cariboo

G.W. Mundy - SO. Ontario

J.R. Oatway - Ottawa Valley

D.M. Dyer

P.M. Morley - SO. Ontario

J.W. McNutt - Algonquin

Lise Robitaille - Orleans

W.W. Lothrop - Ottawa Valley

\section{Approval of Minutes 84th} Annual Meeting

The minutes of the Annual General Meeting were published in The Forestry Chronicle, December 1992 issue.

MOTION G93-1 (G.Taylor, C. Harper)
THAT the minutes be approved.

Carried

\section{Officer's Report}

4.1 President's Report

The President presented his report. It will be published.

MOTION G93 -2 (R. Macnaughton, B. Stoddart)

THAT the report be accepted.

Carried

\subsection{Executive Director's Report}

The Executive Director presented his report. It will be published.

MOTION G93 - 3 (D.Wynia, D. MacArthur)

THAT the report be accepted. Carried

\subsection{Forestry Chronicle Editor's Report}

The Editor, J.H. Cayford, presented his report. It will be published.

MOTION G93 -4 (J.H. Cayford, J. Monty)

THAT the report be accepted.

Carried

\subsection{Forestry Chronicle \\ Production Manager's Report}

The Forestry Chronicle Editor presented the report of the Production Manager, T. Fenton. It will be published.

MOTION G93 - 5 (J. Cayford, J. Monty)

THAT the report be accepted.

Carried

\subsection{Report of Committees}

The Executive Committee summarized the reports of the Membership, Resolutions, Awards, and Archival Committees. After some discussion, it was agreed that members who recently resigned will be contacted by $\mathrm{C}$. Lee to find out why they have not renewed their memberships.

MOTION G93 - 6 (S. Hruszowy, J. Monty)

THAT the reports be accepted.

Carried

\section{Presentation of Awards}

5.1 The President noted that the Canadian Forestry Achievement Award, the Canadian Forestry Scientific Achievement Award, and one of the Fellow Award would be presented at the banquet later that evening. (Recipients were C.H. (Harry) Gairns, Dr. Victor Lieffers and Dr. Bob Bourchier.)

\subsection{Honorary Membership}

An Honorary Membership had been presented to the Honourable John Fraser in May 1993.

\subsection{Fellow Members}

There were two Fellow members as follows:

Ross W. Grinnell and Dr. R.J. Bourchier. 
5.4 Golden Year Certificate

The members for 1993 are D.W. MacLean, J.M. Hope and L.S. Hawboldt.

\subsection{Membership Prize}

The Section Membership prize for obtaining the greatest net percentage increase in membership was presented to the Skeena Section.

\subsection{Gold Medals}

Twenty four Gold Medals were presented during the year to members of the graduation classes of the forestry faculties at the seven universities, as well as 17 forestry technical schools.

\subsection{Schlich Memorial Prize}

The recipient will be a student from Lakehead University.

\section{$5.8 \quad$ Rings}

During the year the CIF/IFC presented rings to 292 students in the graduating classes at seven forestry faculties.

\subsection{Tree of Life Award}

Two Sections named two recipients as follows: Harry Struik, Algonquin Section; Peter Jackson, Nova Scotia Section.

\section{Report of the Chairman, Forest Science and Technology Board} (FSTB)

The Chairman's report was presented by C.A. Lee. It will be published.

MOTION G93-7 (C.A. Lee, R. Braam)

THAT the report be accepted.

Carried

7. Report of President, Forestry Awareness in Canada Trust

C.A. Lee presented the report on behalf of G. Swant. It will be published. It was noted that about 40-50 members contributed $\$ 581.00$ in donations in 1992-93. C. Lee was asked to provide information on FACT.

MOTION G93-8 (C.A. Lee, R. Clark)

THAT the report be accepted. Carried
8.

Finances

8.1 Finance Committee Report

Dr. R.J. Bourchier summarized the

Finance Committee report for 1992 -

93. It will be published.

MOTION G93-9 (R.J. Bourchier,

G. Taylor)

THAT the finance report be accepted.

Carried

The budget was presented by C.A. Lee. It will be printed.

MOTION G93-10 (C.A. Lee, C. Harper)

THAT the budget for 1993-94 be approved.

Carried

\subsection{Auditor's Report}

C.A. Lee summarized the Auditor's report. It will be published.

MOTION G93-11 (C.A. Lee, D. MacArthur)

THAT the report be accepted.

Carried

\subsection{Appointment of Auditor}

MOTION G93-12 (C.A. Lee, D. MacArthur)

THAT Cook, Perry, Sewell and Co. be appointed as auditors for 1993-94, unless new office arrangements allow for more cost effective arrangements.

Carried

\section{9.}

\section{Action Plan}

The Action Plan was presented by Dr. Peter Murphy. It was agreed that additional Dialogues should be written and sent to the new MPs, and that fund raising from workshops be included as part of the Action Plan. (Action Plan 1993-94 is attached as Annex 1).

MOTION G93-13 (P. Murphy, M. Newman)

THAT the Action Plan be accepted.

Carried

\section{By-laws and Rules and Regulations}

Several changes to the By-laws were proposed and discussed.

MOTION G93-14 (C. Harper, R.J. Bourchier)

THAT the By-laws be amended as agreed.

Carried

\section{National Dues 1994-95}

A proposal that national dues for 1994-95 remain the same as 1993-94, if membership levels could be met and other financial savings were realized, was presented by A.A.

Rotherham.

MOTION G93-15 (D. Wynia, P.Y. Bernier)

THAT the dues for 1994-95 increase by 4 per cent, unless total active membership has increased by 2 per cent, by December 31, 1993.

Carried

If a dues increase is put in place for 1994-95 the dues would be as follows:

\begin{tabular}{l}
\multicolumn{2}{c}{ Membership Dues 1994-95 } \\
Active Membership \\
$\begin{array}{lr}\text { 1st and 2nd year after graduation } \\
\text { (grad 1994, grad 1993) }\end{array}$ \\
$\begin{array}{lr}\text { Other new members for } \\
\text { first year }\end{array}$ \\
$\begin{array}{lr}\text { Married or equivalent second } \\
\text { member only \$ }\end{array}$ \\
$\begin{array}{lr}\text { All other active members } & \$ 89.00 \\
& \$ 125.00\end{array}$
\end{tabular}

Other Memberships

Members having retired status, prior to 1990-91 who wish to receive The Forestry

Chronicle. $\$ 40.00$

Members having retired status, prior to 1990-91 who do not wish to receive The Forestry Chronicle.

Members granted retirement status subsequent to 1989-90 $\$ 40.00$ Student members $\$ 20.00$ Sustaining individuals

(CIF/IFC) members $\$ 42.00$

Sustaining Corporate $\$ 260.00$

If a dues increase is not required, dues will remain at the 1993-94 level for 1994-95.

It was noted that Student dues will remain at $\$ 20.00$ next year. The plan is to again combine this attractive rate with a strong push for student members, including posters and Brochures sent to all schools.

\section{Forestry Chronicle} Subscription Rate 1995 and Advertising Rates - 1994

A proposal for 1995 Forestry Chronicle subscription rates was pre- 
sented by C.A. Lee.

MOTION G93-16 (S. Hruszowy,

R. Macnaughton)

THAT the 1995 Forestry Chronicle subscription rates be as follows:

\section{Inside Canada}

Libraries and other

multi-users

$\$ 87.00$

Single user

$\$ 79.00$

Outside Canada

Libraries and other

multi-users

$\$ 105.00$

Single user

$\$ 92.00$

Price of Single Issue

*not more than two years old $1 / 5$ of

annual subscription rate

*more than two years old

$\$ 21.00$

Carried

A proposal for 1994 Forestry Chronicle advertising rates was presented by C.A. Lee.

MOTION G93-17 (C.A. Lee, S. Hruszowy)

THAT the 1994 Forestry Chronicle advertising rates be increased by ten per cent.

Carried

13.

\section{Staffing 1994}

C.A. Lee will continue as Executive Director for an additional year; Denise Trepanier continues as Office Manager; Cherry Maxwell, Membership Clerk; J.H. Cayford, D. Burgess, Editors; T. Fenton, Production Manager.

\section{Future Meetings}

A.A. Rotherham reviewed the meeting schedule for the next three years.

1996 - Thunder Bay, Ontario

1995 - Halifax, Nova Scotia

1994 - Anchorage, Alaska joint with S.A.F.

Representatives from the Anchorage committee and from the cruise line provided information and a slide presentation on Alaska.

\section{Resolutions}

R.J. Bourchier, Acting Chairman of the Resolutions Committee introduced R. Macnaughton, who assisted with the Resolutions.
93.1

WHEREAS: Since the mid-1970's Canada and the provinces and territories have entered into numerous agreements for the purpose of forest development in many aspects of forestry including infrastructure, renewal, maintenance and research and development; and,

WHEREAS: Canada and the provinces have mutually benefitted from these agreements in mutual cooperation and the contribution to sustainable development, especially in the advancement of the science of forestry; and,

WHEREAS: The current generation of federal-provincial development agreements are due to expire anytime up to March, 1996, with some having payout years for completion of approved projects; and,

WHEREAS: A major portion of funding research activities is through these agreements, yielding short term research results with a need for future, as yet unfinanced data gathering to determine long term results; and,

WHEREAS: The government of Canada, in the Spring 1993 Budget, announced that federal-provincial agreements in the sectors of forestry, mining and tourism would not be renewed beyond expiry of the current round on the grounds that these agreements are not an affective method of delivery; and,

WHEREAS : Should these agreements be allowed to expire without replacement in the present or alternate format of funding, research into forest issues will suffer drastic cutbacks affecting government, academic and private research institutions (including consultants);

\section{NOW THEREFORE BE IT RESOLVED, THAT:}

The executive of the Canadian Institute of Forestry/Institut Forestier du Canada be directed to pursue with the federal government at the highest possible level the need for a method of long-term funding of forest research initiatives, thus assuring the viability of Forestry in Canada.

Moved by: Central Ontario Section

Seconded by : North Western Ontario Section.

Carried

\section{2}

WHEREAS: The federal-Provincial forestry agreements have enhanced development of the forest resource, increased our understanding of forest ecosystems, and forestland management and practice; and,

WHEREAS: The federal government has announced that the present round of agreements will not be renewed upon their expiry; and,

WHEREAS: Most Provinces have indicated that they are supportive of renewal of the present agreements; and,

WHEREAS: It is widely acknowledged within the Canadian forest sector that the federal-provincial forestry agreements have been of great benefit and value wherever they have been implemented;

\section{THEREFORE BE IT RESOLVED, THAT:}

The CIF/IFC make representations to the federal government, provincial governments and the forest industry to continue the federal-provincial forestry development agreement programs.

Moved by: Ian Corns, Rocky Mountain Section

Seconded by: Peter Murphy, Rocky Mountain Section

Carried

\section{3}

WHEREAS: The Professional foresters of Nova Scotia are supportive of the formation of a Registered Professional Foresters Association; and,

WHEREAS: The Ad Hoc Committee to form a Registered Professional Foresters Association has developed a Registered Professional Foresters Act; and, 
WHEREAS : The National Forest Strategy entitled "Sustainable Forest: A Canadian Committment", in Section 2.20 calls for government encouragement for the "establishment of legislation where it does not already exist, regarding the professional practice of forestry and the registration and accountability of professional forester"; and,

WHEREAS: The province of Nova Scotia is a signatory to the National Forest Accord;

THEREFORE BE IT RESOLVED, THAT: The Canadian Institute of Forestry/Institut Forestier du Canada in consultation with the Nova Scotia Section, call upon the Premier of Nova Scotia and the Minister of Naural Resources, to:

- introduce the required legislation to enact the Registered Professional Foresters Act as soon as possible; and,

- that the CIF/IFC support the passage of such legislation in Nova Scotia.

Moved by: Rick Archibald, Nova Scotia Section

Seconded by: Guillaume Gignac, Champlain Section

Carried

93.4

WHEREAS: The National Executive
Committee and the Board of Directors of the CIF/IFC have acted on behalf of the combined membership over the past year;

THEREFORE BE IT RESOLVED, THAT: The members of the CIF/IFC at the 85th Annual General Meeting ratify, sanction and confirm all acts, covenants and proceedings made, taken and entered on behalf of the membership by the National Executive Committee and the Board of Directors since the last Annual General Meeting.

Moved by: Gerry Lapointe, Champlain Section

Seconded by: R.J. Bourchier, Ottawa Valley Section

\section{5}

Carried

WHEREAS: The 1993 Annual General Meeting of the CIF/IFC, held jointly in Montreal with the Quebec Order of Forest Engineers, has provided members of the Institute with a truly excellent program to look at Twenty First Century Forestry, an excellent poster session, exhibits, field tours and ample opportunity to sample Montreal's delights;

THEREFORE BE IT RESOLVED, THAT: The Delegates to this 85th Annual General Meeting applaud and express their sincere appreciation to the Champlain Section and the OIFQ and HAMPCO 93 for planning and conducting a first class meeting.

Moved by; All

Seconded; All

16.

The Representatives from Anchorage presented an excellent introduction to what can be expected at the 1994 AGM.

17.

\section{NEW OFFICERS}

President Rotherham introduced the new officers for 1993-94 and thanked Past President A. Whidden for his contributions. He welcomed S. Tolnai as second Vice-President, Dr. Peter Murphy as President, Hap Oldham as first Vice-President and passed the gavel to Peter Murphy. President Murphy provided a brief outline of what he hopes to focus on in 1993-94 and thanked the members for electing him. He presented a gold ring to A.A. Rotherham in recognition of his service to the Institute as President.

\section{ADJOURNMENT}

President Murphy adjourned the 85th Annual Meeting at 17:30.

C.A. Lee, R.P.F. Executive Director October 13, 1993

\section{Annex 1. CIF/IFC Action Plan 1993-94 Banner Issue}

\section{The Institute: New Ways of Doing Things}

To reposition and restructure the $\mathrm{CIF} / \mathrm{IFC}$ on our strengths in four critical respects:

- Mission:

by examining and redefining our membership, mission and role, and writing a new preamble to the By-laws including aims, goal, values, mission statement and objects, and by updating the 1991-94 Strategic Plan to enter the 21st Century.

\section{- Codes:}

by revising the draft National Codes to reflect the CIF/IFC mission

- Membership:

by analyzing membership oppurtunities and immediately acting through Sections upon both membership retention and recruitment, targeting students, foresters and technicians, other professionals and potential sustaining members.

- Institute Management: by acting to identify possible fund-raising projects and cost- saving measures, renegotiate the head office lease, begin staff replacement recruitment as needed, develop more systematic approaches to the process of nominations and awards, and continue to actively foster closer CIF/IFC and RPF relationships.

\section{Other Actions}

2. National Forest Strategy (Sustainable Forests: A Canadian Commitment)

To ensure the success of the 
National Forest Strategy and the CIF/IFC undertakings by:

- actively contributing to the NFS Council and Evaluation Committee, and

- continuing actions to fulfil the CIF/IFC commitments, including Codes and encouragement of RPF associations.

\section{Forestry Education and Accreditation}

To address the expanding scope of forestry, the changing role of forest practitioners, and resulting educational needs of forest practitioners by:

- actively participating in the Forest Education workshop in Quebec City, December 1993, and

- initiating discussion within the CIF/IFC on forestry education needs, and relationship to the accreditation process, and criteria for presentation of Foresters Rings and awarding of Gold Medals.

\section{Continuing Forestry Education}

To encourage members to participate in a variety of Continuing Forestry Education activities and recognize achievement through a Continuing Forestry Education certificate program by:

- developing a CFE structural proposal for presentation to Sections, RPF associations and AUFSC deans for discussion at the December Forestry Education workshop, and

- presenting a complete detailed CFE program working document to CIF/IFC members for approval and action for the fall of 1994.

\section{Representations}

To convey CIF/IFC views on sustainable forestry and changes needed in forest resource management by:

- completing preparation, review and printing of the CIF/IFC Position Statement series,

- conducting a series of Executive Committee meetings with the
Canada Minister for Forestry, federal Opposition forestry leaders, Members of Parliament during a National Forest Week reception, AUFSC forestry deans, CPPA woodlands directors, and the CFPFA, and participating in a number of national committees and workshops,

- encouraging Sections to make similar representations on local and regional issues, and

- continuing discussions in provinces without RPF associations to foster their creation.

\section{Report on the Action Plan 1992-93}

\section{Banner Issue}

The implementation and monitoring of the National Forest Strategy was chosen as the short term banner issue for 1992-93, while the balance of the Action Plan was considered the longer term issue.

\section{Action Plan}

1. National Forest Strategy Followup. The Executive Committee reviewed the Strategy and identified four Strategic Directions that they felt CIF/IFC should take a lead role in. Strategic Direction 2.18 was to define ethics and rules of conduct and their role in support of sustainable development. The work by CIF/IFC and the RPF Associations on Codes of Practice has been addressing this challenge.

Strategic Direction 2.19 was to adopt codes of Ethics, Practice and Professional Conduct. The National Codes developed by CIF/IFC and the RPF Association have now been adopted by all member organizations of CFPFA, except OPFA. A "maintenance committee" has been struck to gather ideas and help the codes to improve and evolve as they come in to use. The CIF/IFC will be contributing to that "evolution".

Strategic Direction 2.20 was to encourage the formation of R.P.F. Associations where they currently do not exist. This was initiated in Saskatchewan by the National Office and in Newfoundland by the Newfoundland Section. Efforts are ongoing in Nova Scotia where legislation has been drafted but has been held up by several factors.

Strategic direction 6.4 was to develop Continuing Education (CE) Programs. CIF/IFC has taken a leadership role in developing a national program with the full participation of all R.P.F. Associations. A report has been prepared for the Directors meeting and the plan is to have the program in place by the end of 1993.

Along with the four items we are taking a lead role in, we are also assisting others in the implementation of other Strategic Directions. For example, we are assisting in developing working definitions for biodiversity (item 1.6) and we are assisting the Deans of Forestry in organizing a workshop to look at the future needs and requirements for the profession (item 6.3) "to meet the broader needs of sustainable forest management".

As well as implementing parts of the Strategy, the CIF/IFC is also an active member of the group that has been created to oversee all aspects of implementation and monitoring. We are represented on the Coalition, on the monitoring committee and on the communications committee. CIF/IFC is well recognized both in the soon to be released newsletter and in the Annual Report which is due in the fall.

2. Codes of Practice. The Executive Committee has pushed for national recognition of the Codes through adoption by all but one RPF Association. Through the Committee set up to improve and evolve the Codes the CIF/IFC will offer its ideas for improvements which will hopefully address Ontario's concerns and allow them to also adopt the national Codes.

The Codes have not yet been linked with Corporate Sustaining Membership.

3. CIF/RPF Cooperation. Recognizing that closer links with the RPF Associations will take time, the 
Executive Committee has focused on programs of national scope that all Associations can cooperate on. These programs include the Canadian Forestry Accreditation Board (CFAB), the National Codes of Practice, and the National Continuing Education Program. Other specific arrangements include the joint 1993 Annual Meeting with the OIFQ, and the recently initiated task force looking at further cooperation with OPFA.

The joint membership arrangements with ARPFA continue to be strong and well accepted. President Rotherham attended the Annual Meeting of ARPFA in June and spoke about the need for cooperation among forestry organizations. While the option of not joining CIF/IFC is available to all ARPFA members, thus far no one has opted out!

\section{Annual General Meeting} Format and Future. The Action Plan recognized that the Annual Meeting must be relevant, cost effective and of a technical nature in order to ensure its usefulness and success. All Annual Meeting organizers are aware and are implementing each of the items put forward in the Action Plan. These include: proper timing, good location, technical content with assistance fron FSTB, and the consideration of joint arrangements where appropriate.

\section{CIF/IFC Organizational Struc-}

ture. In an effort to address this item, a report on the structure of CIF/IFC has been drafted. It is proposed that a workshop session at the Directors meeting be devoted to discussing this report and how it can be used by existing members to better understand the Institute and by potential members as a way of explaining what we do and why they should be a part of it.

Working Group chairs were provided lists of members, pre-addressed envelopes and sheets indicating members' level of interest in the Working Group. The Working Group subject areas require review to ensure relevance. Replacement of some Chairs is also required.
6. Student and Technical Involvement. The efforts of CIF/IFC, outlined in this report, have attempted to build the profile of the Institute and make it an organization that people will want to support. The efforts of some Sections to build profile and attract new members have been excellent.

In an effort to attract students CIF/IFC continues the University News section of the Forestry Chronicle and has introduced the Technical School News. We presented gold medals to 25 universities and technical schools again this year, we offered the Student Directory in the February Chronicle and we have kept student memberships at $\$ 20.00$ for 1993-94. In addition, starting in 199394 a fund has been created to support student activities organized by the Sections. Details of this fund were sent to Sections in March.

In order to further inform and interest students a poster and brochure have been printed and sent to all university and technical schools. A CIF/IFC contact in each faculty has been asked to provide the brochures and answer questions or direct students to the national office for more information.

As a means of attracting more active members, a three for one program has been initiated. If a member signs up three new members prior to December 31, 1993, that member will not have to pay their dues. To assist members in attracting new members, the poster will be available for use by the Sections at meetings or other events and a brochure for potential Active Members has also been printed. The CIF/IFC report on organizational structure may also prove useful in explaining the way CIF/IFC works and what we do.

Student attendance at the AGM is being facilitated by some Sections, many Sections have student representatives on Council and students are encouraged to attend the Directors meeting. A multi-tiered fee is also being looked at.

7. Continuing Education. A full report on the progress of a National
C.E. program has been prepared by Peter Murphy and will be discussed by the Directors.

8. Other Activities. As in previous years, the resolutions from the 1992 AGM generated considerable activity for the Executive Committee.

Resolution 92.1 (increase and stabilize research funding) resulted in a paper prepared for the Forest Sector Advisory Council which proposes ways in which industry may further support research.

Resolution 92.2 (enhance international understanding of sustainable forestry) has led to a paper, prepared jointly by CIF/IFC and OIFQ, which discusses sustainable forestry and indicators thereof. It will be released to the media at the AGM and it is timed to coincide with the meeting of experts of the Conference on Security and Cooperation in Europe which is Meeting in Montreal at the same time as our AGM.

Resolution 92.3 (long term objective of achieving joint membership with the RPF Associations) is being addressed through national efforts such as C.E., CFAB and Codes of Practice and through individual efforts such as arrangements with ARPFA, this joint 1993 AGM with OIFQ and with the task force in Ontario.

Resolution 92.4 (harvest rates based on a thorough assessment of biological and socioeconomic factors) and resolution 92.5 (lands for forest production be identified and set aside) were combined and used as the basis to develop a paper on the need for better information on growth and yield and inventory. The paper was sent to Ministers responsible for health, education, finance, tourism, forestry and other areas that benefit from forestry revenues. It was also sent to major media outlets across Canada. Responses are currently being received and the Executive Committee is considering how to follow-up.

The Action Plan also includes other ongoing activities such as The Forestry Chronicle, cooperation and activities with other groups and the general operation of the Institute. 


\section{Canadian Forestry Achievement Award Charles Henry (Harry) Gairns}

Starting with his education in forestry, and continuing throughout his career, Harry Gairns has exemplified hard work, excellence and a commitment to the profession of forestry.

Harry's accomplishments began with a distinguished university career which included receiving several undergraduate bursaries and scholarships, the BC Coast Woods Prize in Engineering and the BC Lumber Manufacturers' Association Prize for structural design. Upon graduation he received the Canfor prize for highest standing in the last two years of forest engineering, the H.R. MacMillan prize for highest standing in the graduating year in Forest Engineering and the CIF/IFC Gold Medal for best overall record in Forestry or Forest Engineering. (Harry likes to mention that he received the CIF/IFC Gold Medal back when it really was a gold medal.)

Harry has been a member of the Association of BC Professional Foresters since 1958, was a member of their Council from 1975 to 78 , served as President in 1977 and was a member of their Discipline Committee from 1984 to 89 .

He has been a member of the Association of Professional Engineers and Geoscientists of BC since 1963, chaired their Prince George Branch in 1972, was a member of Council from 1983 to 85 , chaired the External Affairs Committee from 1984 to 85 , was a member of the Discipline Committee from 1988 to 89 and received the R.A. McLachlin Memorial Award for Professional and Community Service in 1975.

$\mathrm{He}$ has been a member of the Consulting Foresters of BC since 1968 , served in various positions and was their President as well, in 1971.

With CIF/IFC, which he joined in 1954, he chaired the Cariboo Section in 1961, served on the National Board of Directors in 1962, was a member of the National Executive from 198889 to $1991-92$, serving as our National President in 1990-91.

He has worked on many advisory committees, commissions, boards, church groups, ski association functions and other profesional and social activities. He is currently serving on the Natural Sciences and Engineering Research Council.

This list reads like the accomplishments and activities of about three or four people and gives you a good idea of how Harry approaches everything he does. When asked their opinion on his qualifications for this award many people responded with equal enthusiasm. His colleagues told us that "Harry maintains the great respect of all his associates for his innovative thinking, clear ideas, sharpness of mind, dependability and professionalism". Others said, "for the past 37 years (he has been) a complete professional, dedicated to forestry in all its aspects"; and (his achievements have) "earned him the respect of his colleagues from coast to coast". He was described as "an ardent supporter of good forest management", "a diligent worker" with "strong leadership and superior accomplishments", "one of the outstanding foresters in the province of $\mathrm{BC}$ " and "a pioneer of wise use forestry".

The recognition of one's colleagues is perhaps the highest praise one can hope to receive.

For his lifetime of dedication to the practice of forestry, the Canadian Institute Forestry/Institut Forestier du Canada, is proud to present Charles Henry (Harry) Gairns with the Canadian Forestry Achievement Award for 1993.

\section{Canadian Forestry Scientific Achievement Award 1993 Dr. Victor J. Lieffers}

Dr. Lieffers is a tenured Associate Professor in the Department of Forest Science at the University of Alberta.
Dr. Lieffers teaches Silviculture and Advanced Forest Ecology and recently offered a course on Forest Competition. He is highly regarded as an educator and his students describe him as an effective professor but he is more than an undergraduate teacher.

Vic is an excellent graduate supervisor and research scientist. Since 1986 he has supervised 10 graduate students and has served on about 30 graduate level committees and his work on these committees has been recognized by three different departments on campus. He is well known nationally and internationally and has served as External Examiner on Ph.D. committees at UNB and UBC.

Since 1983, he has published over 32 referred journal articles, 6 major reports or conference proceedings, has generated over $\$ 675,000$ in forest research funding and has refereed over 160 journal manuscripts. Vic has also served as an associate editor of the Canadian Journal of Botany, a position frequently reserved for more senior scientists.

Dr. Lieffers' most recent work has focused on the ecology, morphology, and physiology of Calamognostis canadensis and how this information can be used to more efficiently establish white spruce in Alberta. Prior to this direction of research, Vic spent four years developing an understanding of how true growth and biomass decomposition is affected by cold soils and high water table depths. Vic's work is now recognised as the standard by which all other boreal ecology work is judged. His capability has been recognized by NSERC, who asked him to serve as a member on one of their project review teams.

Dr. Lieffers' expertise goes beyond the usual scope of science as well. During 1991, he served as an expert witness for the Province of Alberta in court proceedings involving the Alberta Forest Service, Daishowa and a number of environmental groups. While the testimony of "expert" witnesses for the environmental groups 
was, in the words of Judge McDonald, "entitled to little weight", Dr. Lieffers' expert testimony contributed significantly to the Judge's ability to understand the ecological and management implications of forestry in Alberta and the decision was made in favour of the Alberta
Forest Service and Daishowa.

Dr. Lieffers is an extremely productive educator and scientist by anyone's standards. His contributions to the science and practice of forestry have been substantial and well recognized by his peers and by those outside his field. He has been a member of the Canadian Institute of Forestry for 10 years and has contributed to the profession in many ways. The Canadian Institute of Forestry takes great pride in honouring Dr. Victor J. Lieffers and presents him the Canadian Forestry Scientific Achievement Award for 1993.

\section{STORA FELDMÜHLE}
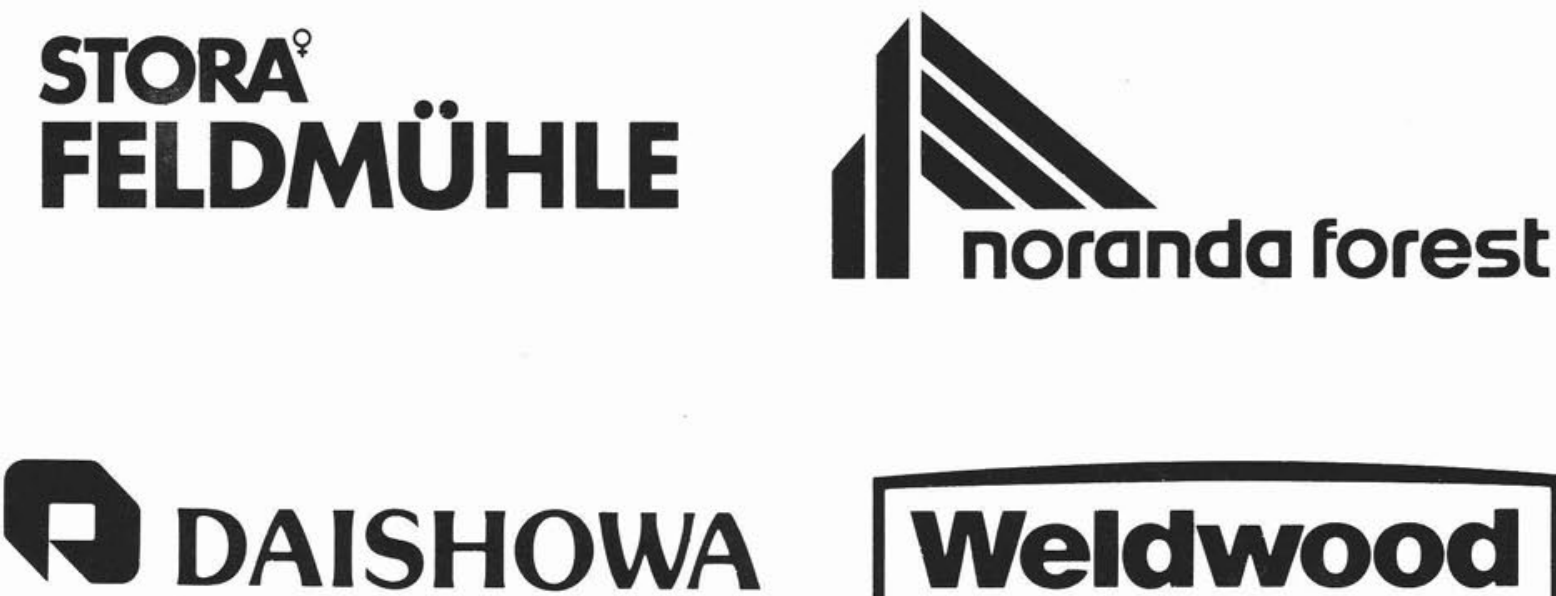

\section{Weldwood}
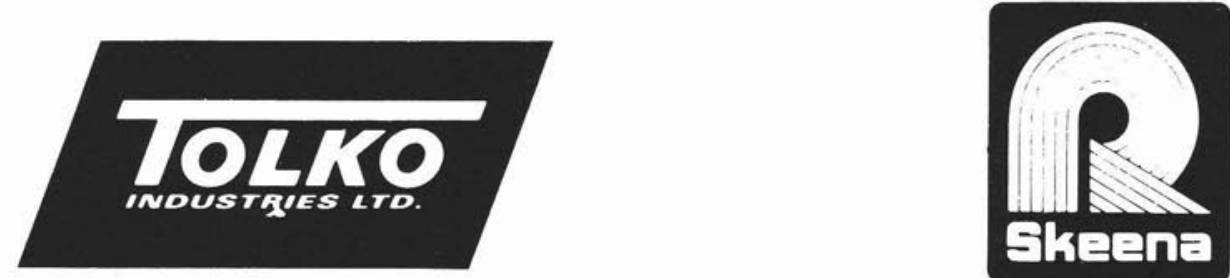

\section{CIF/IFC Corporate Sustaining Members}

